\title{
mRNA and Protein Expression of Selective Alpha Subunits of G Proteins are Abnormal in Prefrontal Cortex of Suicide Victims
}

Yogesh Dwivedi, Ph.D., Hooriyah S. Rizavi, M.S., Robert R. Conley, M.D., Rosalinda C. Roberts, Ph.D., Carol A. Tamminga, M.D., and Ghanshyam N. Pandey, Ph.D.

The present investigation was undertaken to examine whether there is an abnormality in the expression of $\alpha$ and $\beta \gamma$ subunits of $G$ proteins both at the transcriptional and translational level in postmortem brain of adult and teenage suicide subjects and whether these abnormalities are related to mental disorders or suicide per se. In addition, an attempt has been made to investigate whether these abnormalities are similar or dissimilar in teenage and adult suicide, because the etiology of teenage suicide may be different than that of adults.

A significant decrease in both $m R N A$ and protein levels of $G_{i 2} \alpha$ and $G_{O} \alpha$ and a significant increase in levels of $G_{s} \alpha_{-S}$ were observed in prefrontal cortex of suicide subjects $(n=$ 43) compared with non-psychiatric control subjects ( $n=$ 38). When subjects were grouped according to age, a significantly decreased expression of $G_{i 2} \alpha$ and $G_{O} \alpha$ and significantly increased expression of $G_{s} \alpha_{-s}$ were observed in adult suicide subjects (age $\geqslant 20$ yrs; $n=20$ ) as compared with age-matched controls $(n=27)$. These changes were present in all adult suicide subjects regardless of psychiatric diagnosis. On the other hand, although there were no significant differences in any $\alpha$ or $\beta \gamma$ subunits in teenage suicide subjects (age $\leqslant 19$ yrs; $n=16$ ) when compared with matched control subjects $(n=18)$; however, $m R N A$ and protein levels of $G_{i 2} \alpha$ and $G_{O} \alpha$ were significantly decreased and of $G_{s} \alpha_{-s}$ were significantly increased only in those teenage suicide subjects who had a history of mental illness $(n=11)$. Our results suggest that there are defects in the expression of selective $G$ protein $\alpha$ subunits in prefrontal cortex of adult and teenage suicide subjects, which appear to be related to mental disorders.

[Neuropsychopharmacology 27:499-517, 2002] (C) 2002 American College of Neuropsychopharmacology. Published by Elsevier Science Inc.
KEY WORDS: G proteins; Suicide; Postmortem brain; Human; Immunolabeling; $m$ RNA

From the Psychiatric Institute, Department of Psychiatry, University of Illinois at Chicago, 1601 West Taylor Street, Chicago, IL (YD, HSR, GNP), and Maryland Psychiatric Research Center, Baltimore, Maryland, USA (RRC, RCR, CAT).

Address correspondence to: Ghanshyam N. Pandey, Ph.D., Professor, Psychiatric Institute, Department of Psychiatry, University of Illinois at Chicago, 1601 W. Taylor Street, Chicago, IL 60612. Tel.: (312) 413-4540; Fax: (312) 413-4547/4544; E-mail: gpandey@psych. uic.edu

Online publication: $3 / 21 / 02$ at www.acnp.org/citations/ Npp032102272.

Received August 20, 2001; revised March 14, 2002; accepted March 18, 2002.
Suicide is a major public health concern. In the past several years there have been a number of studies suggesting an association of suicidal behavior with neurobiological abnormalities. The precise molecular mechanisms associated with suicidal behavior, however, remain unclear. Several studies have implicated various neurotransmitter receptors, such as serotonin $(5 \mathrm{HT})_{2 \mathrm{~A}}$, $5 \mathrm{HT}_{1 \mathrm{~A}}, \alpha_{1^{-}}, \alpha_{2^{-}}$, and $\beta$ adrenergic, as well as GABA, in the pathophysiology of suicide (reviewed by Gross-Isseroff et al. 1998; Pandey et al. 2002). The functional properties of these receptors, however, lie in their ability to relay extracellular messages through various signal transduction mechanisms. In this respect, guanine nucleotide binding proteins (G proteins) occupy a cen- 
tral position and play a critical role in transducing extracellular messages from cell surface receptors to effectors. About $80 \%$ of the receptors for neurotransmitters, hormones, and neuromodulators have been shown to elicit their responses through $\mathrm{G}$ proteins (Birnbaumer et al. 1990; Spiegel et al. 1990).

Structurally, $\mathrm{G}$ proteins are composed of three subunits, $\alpha, \beta$, and $\gamma$, each encoded by a specific gene. $\beta$ and $\gamma$ subunits bind tightly to each other. Whereas the $\beta$ subunit contains a common binding site for $\alpha$ subunit recognition, the $\alpha$ subunit binds to guanosine trisphosphate (GTP) and confers receptor effector specificity to $\mathrm{G}$ proteins. The $\gamma$ subunit has been reported to have a $\mathrm{G}$ protein-specific receptor recognition site (Tamir et al. 1991). Receptor-mediated activation of $G$ proteins causes the release of guanosine diphosphate (GDP) from the $\alpha$ subunit, allowing GTP to bind and induce the dissociation of the $G$ protein $\alpha$ subunit from the $\beta \gamma$ subunits. The $\alpha$ and the $\beta \gamma$ subunits can then activate various effectors to modulate cellular responses (Neer 1995; Clapham and Neer 1997; Hamm 1998; Freissmuth et al. 1999).

On the basis of cDNA sequencing and the similarity of amino acid sequences, $\mathrm{G} \alpha$ subunits have been classified into four major classes: $G_{\mathrm{s}}, G_{\mathrm{i}}, \mathrm{G}_{\mathrm{q}}$, and $\mathrm{G}_{12}$. More than 16 distinct genes encode the $G$ protein $\alpha$ subunits with a splice variant from at least two genes (Gilman 1987; Simon et al. 1991; Neer 1995; Clapham and Neer 1997; Hamm 1998). Five distinct $\beta$ subunit genes and 12 $\alpha$ subunit genes have also been identified (Clapham and Neer 1997; Hildebrandt 1997). Once dissociated, both $\alpha$ and $\beta \gamma$ subunits can activate or inhibit multiple effectors to modulate cellular responses. These effectors include adenylyl cyclase, phospholipase $C$, phosphodiesterases, phospholipase $\mathrm{A}_{2}$, and phosphoinositide 3 kinase, thereby inhibiting or activating a variety of second messengers, such as cAMP, cGMP, diacylglycerol, inositol $(1,4,5)$ trisphosphate, phosphatidylinositol $(3,4,5)$ trisphosphate, arachidonic acid, and phosphatidic acid, in addition to promoting increases in intracellular $\mathrm{Ca}^{2+}$ and the opening and closing of a variety of ion channels (Marinissen and Gutkind 2001). Recent studies demonstrate that different classes of $G$ proteins can couple to a single receptor. This occurs through molecular switching of one $G$ protein:effector system to a different $G$ protein:effector system, triggered by agonist-mediated phosphorylation of receptors (Daaka et al. 1997; Lefkowitz 1998; Luo et al. 1999).

Because of the critical role of $\mathrm{G}$ proteins in signaling systems, studies in recent years have focused on their involvement in the pathophysiology of mental disorders, including affective disorders (Ozawa et al. 1993; Garcia-Sevilla et al. 1997, Young et al. 1993; Manji et al. 1995; Friedman and Wang 1996; Vawter et al. 2000), panic disorder (Stein et al. 1995; Gurguis et al. 1999a,b), Parkinson's disease (Avissar et al. 1997), schizophrenia (Jope et al. 1998), alcoholism (Hoffman and Tabakoff
1990; Jope et al. 1998), and also in the mechanisms of action of psychoactive drugs (reviewed by Manji 1992; Dwivedi and Pandey 1997). The role of G proteins in suicidal behavior, however, has not been evaluated in greater detail. There are a few studies that have examined abnormalities in the expression of $G$ protein subunits in postmortem brain of suicide subjects (Cowburn et al. 1994; Pacheco et al. 1996; Garcia-Sevilla et al. 1999). However, the findings of these studies are inconsistent and do not clarify whether the alterations in $G$ proteins are associated with mental disorders or suicide per se. Furthermore, from these studies it is not clear whether the alterations in levels of $G$ protein subunits are due to a defect at the translational level or to a defect in gene transcription.

In the present investigation, we comprehensively studied the role of $G$ proteins in suicidal behavior by examining the gene transcription as well as the protein levels of various $\alpha$ and $\beta \gamma$ subunits of $G$ proteins in postmortem brain of a large number of suicide subjects, which include subjects with and without a history of mental disorders.

An interesting aspect of this study is the inclusion of postmortem brain samples from teenage suicide subjects (age $\leqslant 19$ yrs). Although the neurobiology of adult suicide has been studied, the neurobiology of teenage suicide has been virtually unexplored. Psychological and psychosocial studies suggest that some factors associated with teenage suicide may be different than in adult suicide. Whereas teenage suicide is thought to be driven primarily by impulsive, aggressive, and violent behaviors (Brent et al. 1993), adult suicide appears to be associated with chronic mental disorders. It is, thus, quite possible that the alterations in expression of $G$ protein subunits may be different in postmortem brain of teenage suicide subjects than of adult suicide subjects.

Our present study thus clarifies several issues, namely whether: (1) there are any difference in levels of $G$ protein subunits in postmortem brain of suicide subjects; (2) alterations in levels of $G$ protein subunits occur at the transcriptional level; (3) alterations in expression of $\mathrm{G}$ protein are related to mental disorders; and (4) alterations in $G$ protein subunit expression are different in teenage than in adult suicide.

\section{MATERIALS AND METHODS}

\section{Postmortem Brain Samples}

Postmortem brain samples from 43 adult and teenage suicide and 38 non-psychiatric control subjects, herein referred to as control subjects, were collected by the Brain Collection Program of the Maryland Psychiatric Research Center, Baltimore, MD, in collaboration with the Medical Examiner's Office of the State of Maryland. 
The present studies were performed in prefrontal cortex (Brodmann's area (BA) 8/9) obtained from the right hemisphere of the brain. All the cases were examined neuropathologically prior to inclusion in the study. Cases with signs of atrophy, infarcts or gross anatomical abnormality were excluded from this study. These brain samples were also negative to HIV antibodies. To make sure that tissues were taken from the same anatomic level, sections were prepared from tissue blocks and Nissl stained. The tissue sections were matched across the control and suicide groups. Toxicology data of subjects were obtained by analysis of urine and blood samples. The biochemical determinations were performed in parallel between control and suicide subjects. Each determination was measured in duplicate per subject.

We elected to analyze BA $8 / 9$ since most of the previous $G$ protein studies have been performed in this brain area (Pacheco et al. 1996; Garcia-Sevilla et al. 1999). Furthermore, we have a long-standing interest in the dorsolateral prefrontal cortex since this brain area has been shown to play a relevant role in mood regulation (George et al. 1994) and has been implicated in the pathophysiology of affective disorders and suicide in a number of neurochemical studies (reviewed by Rajkowska 1997; Sastre et al. 2001). In our own studies, we have observed several interesting findings in BA 8/9 of suicide victims, such as a higher number of $5 \mathrm{HT}_{2 \mathrm{~A}}$ receptors, increased expression of mRNA and protein of $5 \mathrm{HT}_{2 \mathrm{~A}}$ receptors (Pandey et al. 2002), and abnormalities in phosphoinositide (Pandey et al. 1997, 1999), adenylyl cyclase-cAMP (Dwivedi et al. 2002), and mitogen-acivated protein kinase (Dwivedi et al. 2001) pathways.

All subjects in this study were diagnosed in the following manner: after giving written informed consent, at least one family member was interviewed, based on the Diagnostic Evaluation After Death (DEAD) (Salzman et al. 1983), the Schedule for Clinical Interviews for the DSM-IV (SCID) (Spitzer et al. 1992), or a teenage diagnostic instrument, the Kiddie Schedule for Affective Disorders and Schizophrenia (KIDDISADS). Family members gave permission for clinical records to be obtained from mental health treatment providers when there was a history of mental health treatment, and in all cases of suicide. An attempt was made to collect all the available records on each case, and then the appropriate data were extracted from the records and collated using the DEAD. Two senior psychiatrists provided independent DSM-IV diagnoses. These diagnoses were compared and discrepancies were resolved by means of a consensus conference. Similarly, controls were verified as free from mental illness using such consensus diagnostic procedures. Data on suicide cases were collected and the circumstances of the suicide were determined using the DEAD form during the same interview process. The protocols for tissue sampling and retro- spective assessments were approved by the Institutional Review Board (IRB) of the University of Maryland. This study was also approved by the IRB of the University of Illinois at Chicago.

The demographic characteristics of suicide and control subjects are provided in Table 1 . There were 31 males and 7 females in the control group and 27 males and 16 females in the suicide group. The age range was 12-87 years and the postmortem interval (PMI) was in the range of 5-35 $\mathrm{h}$. We observed that there were no significant differences in age $(\mathrm{t}=0.05, \mathrm{df}=79, p=.96)$ or PMI $(\mathrm{t}=0.10, \mathrm{df}=79, p=.91)$ between suicide and control subjects. To determine the agonal state, brain $\mathrm{pH}$ was measured by homogenizing a piece of cerebellum in 15 volumes of distilled water, and the acidity was measured by a $\mathrm{pH}$ meter. There were no significant differences in $\mathrm{pH}$ of the brain between control and suicide subjects $(\mathrm{t}=0.002, \mathrm{df}=79, p=.99)$, as it ranged from 5.35 to 6.85 . The tissue storage time was in the range of 3.9-7.6 years and did not differ between control and suicide subjects $(\mathrm{t}=1.5, \mathrm{df}=79, p=.13)$.

When control and suicide subjects were subdivided on the basis of age (adult $\geqslant 20 \mathrm{yrs}$; teenage $\leqslant 19 \mathrm{yrs}$ ), there were 27 adult suicide subjects and 20 adult controls, and 16 teenage suicide subjects and 18 teenage control subjects. There were no significant differences in age $(\mathrm{t}=0.63, \mathrm{df}=45, p=.53)$ or PMI $(\mathrm{t}=0.07, \mathrm{df}=$ $45, p=.95)$ between adult suicide and adult control subjects, as well as in age $(\mathrm{t}=1.7, \mathrm{df}=32, p=.08)$ or PMI $(t=0.02, \mathrm{df}=32, p=.98)$ between teenage suicide and teenage control subjects. There were 16 male and 4 female subjects in the adult control group and 17 male and 10 female subjects in the adult suicide group. In the teenage control group, there were 15 male and 3 female subjects, whereas in the teenage suicide group, there were 10 male and 6 female subjects. The distribution of races in the adult and teenage populations was as follows: 8 black and 12 white in adult control; 4 black and 23 white in adult suicide; 12 black and 6 white in teenage control; and 3 black, 11 white, and 2 of other races in teenage suicide group.

\section{Quantitation of G Proteins by Western Blot}

Gel electrophoresis and immunolabeling of $G$ protein subunits $\left(\mathrm{G}_{\mathrm{s}} \alpha_{-\mathrm{S}}, \mathrm{G}_{\mathrm{s}} \alpha_{-\mathrm{L}}, \mathrm{G}_{\mathrm{i} 1} \alpha, \mathrm{G}_{\mathrm{i} 2} \alpha, \mathrm{G}_{\mathrm{O}} \alpha, \mathrm{G}_{\mathrm{q} / 11} \alpha, \mathrm{G} \beta\right.$ and $\mathrm{G} \gamma$ ) were performed by Western blot as previously reported (Dwivedi and Pandey 1997). Equal amounts of protein samples $(25 \mu \mathrm{g}$ protein in each lane) were loaded onto $12 \%(\mathrm{w} / \mathrm{v})$ acrylamide gel and subsequently transferred electrophoretically to enhanced chemiluminescent (ECL) nitrocellulose membranes (Amersham Pharmacia, Piscataway, NJ). The blots were incubated overnight at $4^{\circ} \mathrm{C}$ with primary antibody for $\mathrm{G}_{\mathrm{s}} \alpha, \mathrm{G}_{\mathrm{q} / 11} \alpha, \mathrm{G}_{\mathrm{O}} \alpha$ (NEN Research Products, Boston, MA) 


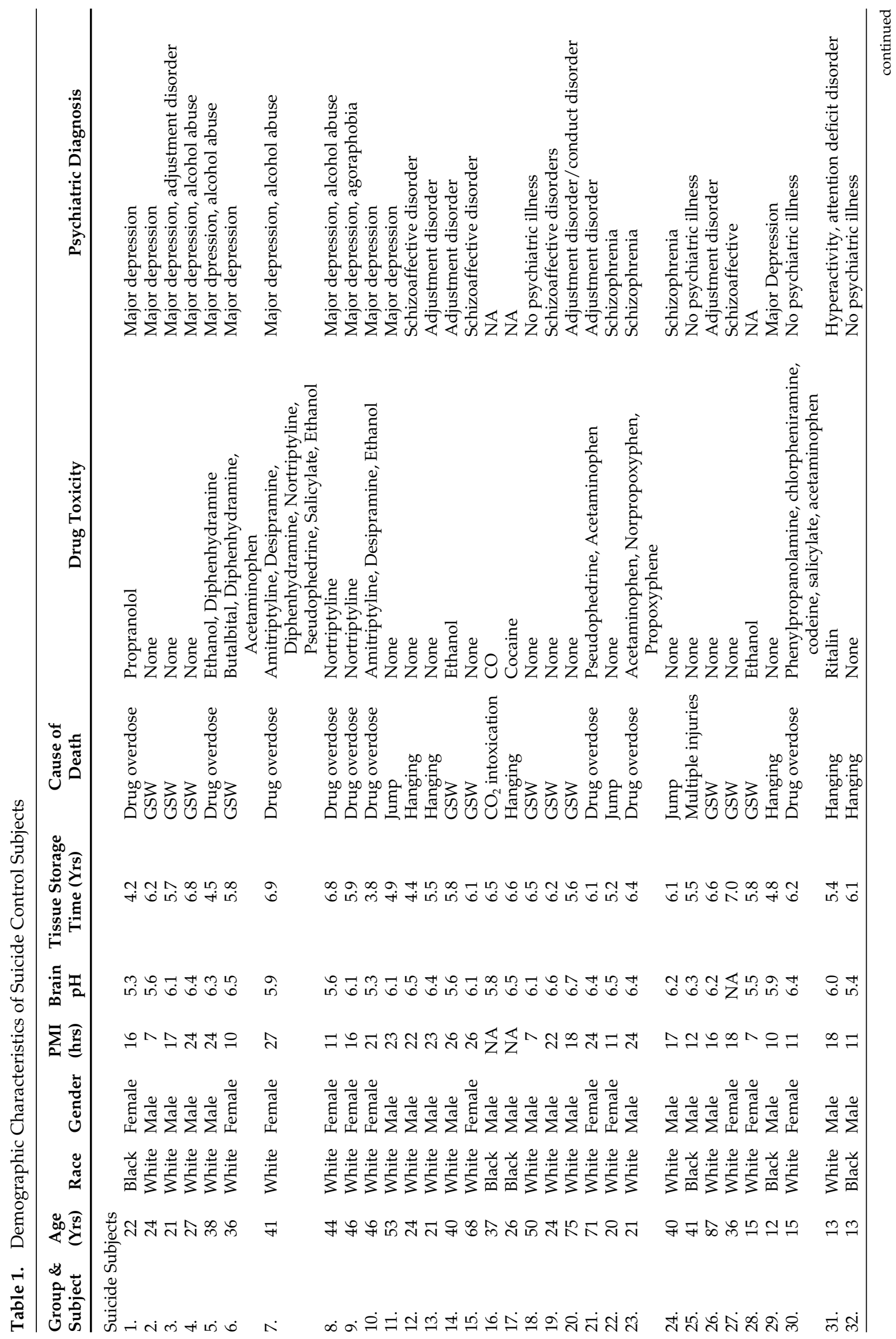




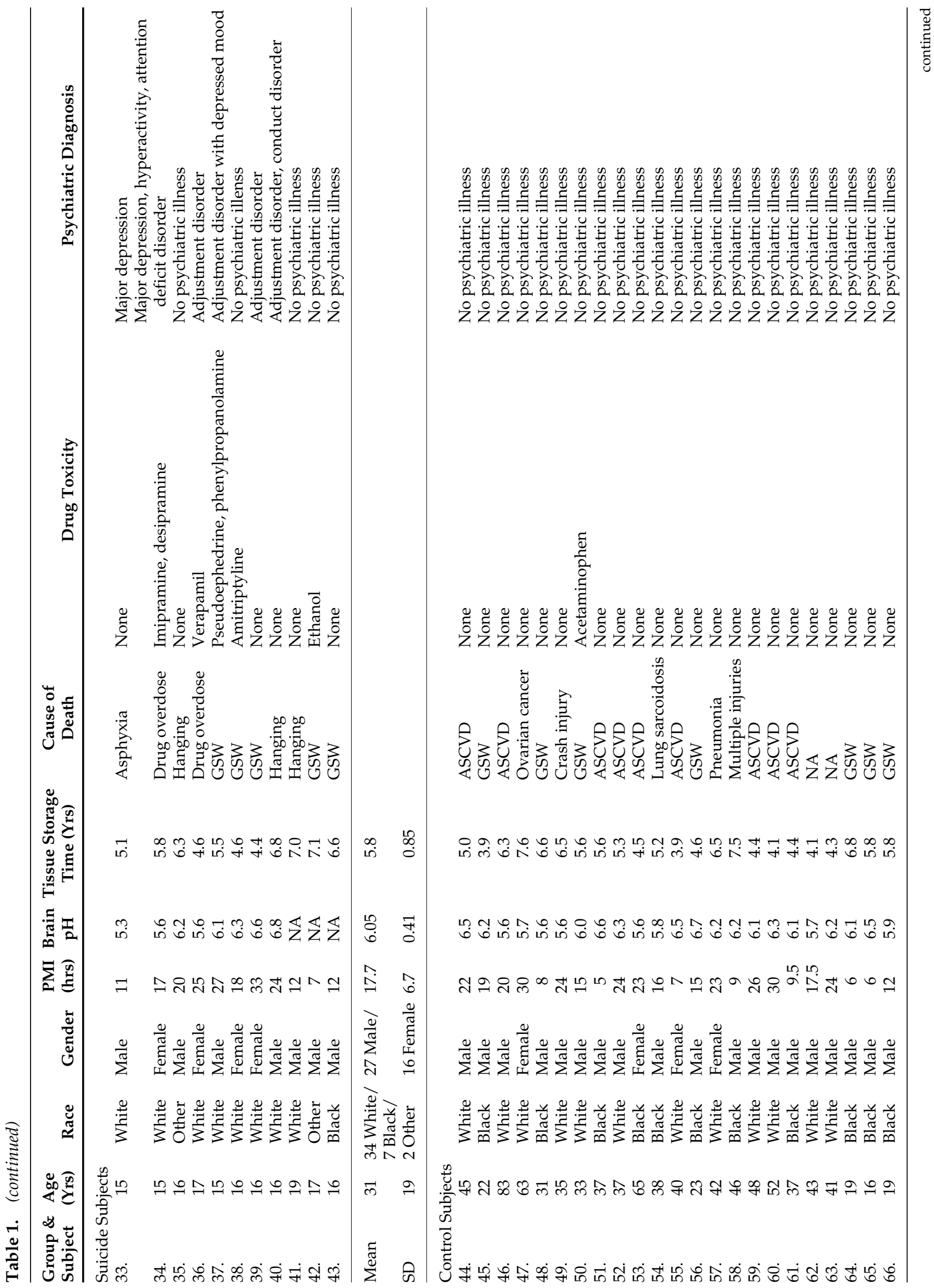




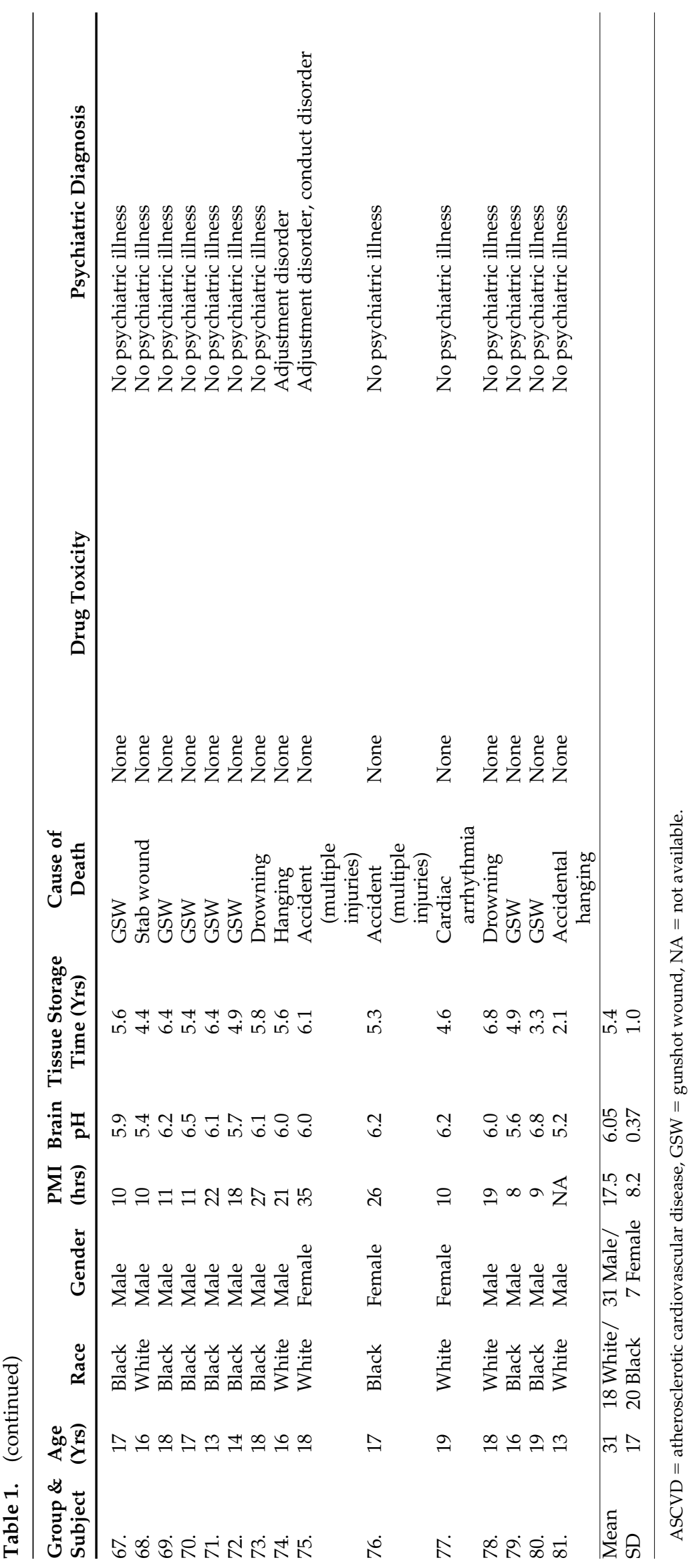


$\mathrm{G}_{\mathrm{i} 1} \alpha, \mathrm{G}_{\mathrm{i} 2} \alpha$ or $\mathrm{G} \beta \gamma$ (Calbiochem, San Diego, CA) at a dilution of 1:3000 to 1:5000 (depending on the antibody used) and with horseradish-peroxidase-linked secondary anti-rabbit antibody (Amersham Pharmacia) for 3 to $5 \mathrm{~h}$ at room temperature. The signals were detected with the ECL Western Blot Detection System (Amersham), followed by exposure to ECL-autoradiographic film (Amersham). The membranes were stripped using stripping solution (Chemicon International, Temecula, $\mathrm{CA})$, and probed with $\beta$-actin monoclonal primary (1:5000 for $1 \mathrm{~h}$, Sigma Chemical Co., St. Louis, MO) and anti-mouse secondary antibody (1:5000 for $1 \mathrm{~h}$ ). The bands on the autoradiograms were quantified using the Loats Image Analysis System (Westminster, MD). The optical density of each $\mathrm{G}$ protein subunit was corrected by the optical density of the corresponding $\beta$-actin band.

\section{Determination of mRNA Levels of $G_{S} \alpha, G_{i 1} \alpha, G_{i 2} \alpha$, and $\mathrm{G}_{\mathrm{O}} \alpha$ by Competitive Reverse Transcriptase Polymerase Chain Reaction (RT-PCR)}

Total RNA from BA 8/9 was isolated by $\mathrm{CsCl}_{2}$ ultracentrifugation as described earlier (Dwivedi et al. 2001). The primer pairs were designed to allow amplification for $\mathrm{G}_{\mathrm{S}} \alpha$ (518-841 bp; Bray et al. 1986; GenBank accession \# M14631), $\mathrm{G}_{\mathrm{i} 1} \alpha$ (487-882 bp; Bray et al. (1987); GenBank accession \# NM002069), $\mathrm{G}_{\mathrm{i} 2} \alpha$ (483-884 bp; Didsbury et al. (1987); GenBank accession \# 31743), and $\mathrm{G}_{\mathrm{O}} \alpha$ (506-818 bp; Zigman et al. (1994); GenBank accession \# L10665). Each primer contained a comparable G/C content to minimize the variability in hybridization efficiency at the annealing temperature. The sequences and the positions of external primers and the percent of $\mathrm{G} / \mathrm{C}$ content of each primer are given in Table 2. The specificity of $G_{s} \alpha, G_{i 1} \alpha, G_{i 2} \alpha$, and $G_{O} \alpha$ products was checked by sequencing the amplified area with the Sequenase Version 2.0 DNA Sequencing Kit.

Internal standards (cRNA) for the various $G$ protein subunits were prepared by site-directed mutagenesis using PCR overlap extension, as described earlier
(Dwivedi et al. 2001). Each standard was designed to introduce a BglII or XhoI restriction site midway between the amplification primers so that the digestion of the amplicon would generate two fragments of approximately equal molecular size. The designs for each internal primer are provided in Table 3. The internal standard templates were linearized with SspI. The cRNA corresponding to sense strand was synthesized with linearized template and Sp6 RNA polymerase by means of an in vitro transcription kit.

To quantitate the mRNA levels of the various $G$ protein subunits, decreasing concentrations of internal standard cRNA were added to $1 \mu \mathrm{g}$ of RNA and the mixture of total RNA and RNA/cRNA was reversetranscribed with cloned Moloney murine leukemia virus (M-MLV) and reverse-transcriptase (200 U). The RT mixture was incubated at $37^{\circ} \mathrm{C}$ for $60 \mathrm{~min}$ to promote cDNA synthesis. The reaction was terminated by heating the tissue samples at $98^{\circ} \mathrm{C}$ for $5 \mathrm{~min}$. In all assays, as a control, one RT reaction was performed in the absence of RNA.

The PCR mixture was amplified for 30 cycles $\left(94^{\circ} \mathrm{C}, 15\right.$ $\left.\mathrm{s} ; 60^{\circ} \mathrm{C}, 30 \mathrm{~s} ; 72^{\circ} \mathrm{C}, 30 \mathrm{~s}\right)$ using $0.5 \mu \mathrm{M}$ specific primer pairs, $200 \mu \mathrm{M}$ dNTPs, $1.5 \mathrm{mM} \mathrm{MgCl} 2,50 \mathrm{mM}$ Tris/HCl ( $\mathrm{pH}=9.0), 20 \mathrm{mM}$ ammonium sulfate, $15 \mathrm{mM} \mathrm{KCl}, 1 \mu$ $\mathrm{Ci}$ of ${ }^{32} \mathrm{PdCTP}$ and $2.5 \mathrm{U}$ of Hot Tub DNA polymerase. Following amplification, aliquots were digested with restriction enzyme in triplicate and run by $1.5 \%$ agarose gel electrophoresis. To quantitate the amount of product, the ethidium bromide-stained bands were excised and counted. The results were calculated as the counts incorporated into the amplified cRNA standard divided by the counts incorporated into the corresponding mRNA amplification product versus the known amount of internal standard (cRNA) added to the test sample

\section{Statistical Analysis}

Data analyses were performed using the SPSS 8.0 (Chicago, IL) statistical software package. All values re-

Table 2. External Primer Sequence of $G_{S} \alpha, G_{i 1} \alpha, G_{i 2} \alpha$ and $G_{O} \alpha$ for Amplification

\begin{tabular}{llcc}
\hline & \multicolumn{1}{c}{ Primers } & \% (C + G) & Nucleotide Position \\
\hline $\mathrm{G}_{\mathrm{S}} \alpha$ & F: 5' ACG TGA TCA AGC AGG CTG ACT & 52 & $548-568$ \\
& R: 5'GGA ACA GGA TCA CAG AGA TGG & 52 & $851-871$ \\
$\mathrm{G}_{\mathrm{i} 1} \alpha$ & F: 5' GCT CAA CCA AAT TAC ATC CCG & 47 & $487-507$ \\
& R: 5'GTT TGA TCC TGC ATA TTC TGG & 43 & $862-882$ \\
$\mathrm{G}_{\mathrm{i} 2} \alpha$ & F: 5'GCG TAT TGC ACA GAG TGA CTA & 47 & $483-503$ \\
& R: 5'TTG GCC CCT GTG TAC TCA GGG & 61 & $864-884$ \\
$\mathrm{G}_{\mathrm{O}} \alpha$ & F: 5'TCG ACA GCG TCA GCT TGG TTG & & $506-526$ \\
& R: 5'GAA ATG GTC CGT AAC CAC CTG & 61 & $798-818$ \\
\hline
\end{tabular}

$\mathrm{F}=$ Forward; $\mathrm{R}=$ Reverse. 
Table 3. Internal Primer Sequence of $G_{S} \alpha, G_{i 1} \alpha, G_{i 2} \alpha$ and $G_{O} \alpha$ for Site-directed Mutagenesis

\begin{tabular}{|c|c|c|c|c|}
\hline Primers & & Restriction endonuclease & $\%(C+G)$ & Nucleotide position \\
\hline \multirow[t]{2}{*}{$\mathrm{G}_{S} \alpha$} & 5'AGT GGA TCC AGA TCT TCA ACG ATG & \multirow[t]{2}{*}{$B g l I I$} & 46 & \multirow[t]{2}{*}{$668-691$} \\
\hline & 5'CAT CGT TGA $\underline{\overline{\mathrm{AGA} T C \mathrm{~T}}}$ GGA TCC ACT & & 46 & \\
\hline \multirow[t]{2}{*}{$\mathrm{G}_{\mathrm{i} 1} \alpha$} & 5'TAC GAC CTG GCT CGA GCT GAA GAT & \multirow[t]{2}{*}{ XhoI } & 54 & \multirow[t]{2}{*}{$688-711$} \\
\hline & 5'ATC TTC AGC TCG AGC CAG GTC GTA & & 54 & \\
\hline \multirow{2}{*}{$\mathrm{G}_{\mathrm{i} 2} \alpha$} & 5'CTT CTG CGT AGA TCT GAG CGC CTA & \multirow[t]{2}{*}{$B g l \mathrm{II}$} & 54 & \multirow{2}{*}{$669-692$} \\
\hline & 5'TAG GCG CTC $\overline{\text { AGA TCT ACG CAG AAG }}$ & & 54 & \\
\hline \multirow[t]{2}{*}{$\mathrm{G}_{\mathrm{O}} \alpha$} & 5'GAA AAT GGC TCG AGT GCT TTAACG & \multirow[t]{2}{*}{ XhoI } & 46 & \multirow[t]{2}{*}{$656-679$} \\
\hline & 5'CGT TAA AGC ACT CGA GCC ATT TTC & & 46 & \\
\hline
\end{tabular}

Italicized letters indicate the mutated bases. Underlined bases indicate cleavage site.

ported are the mean \pm the standard deviation (S.D.). The differences in mRNA and protein levels of the various subunits of G protein, age, and PMI between suicide and control subjects were analyzed using the independent-sample $t$-test. The relationships between the mRNA and protein levels of $G$ protein subunits, and PMI, age, and gender were determined by Pearson product-moment correlation analysis. $p$ values were 2-tailed. The statistical differences in levels of $G_{s} \alpha_{-S}$, $\mathrm{G}_{\mathrm{i} 1} \alpha, \mathrm{G}_{\mathrm{i} 2} \alpha, \mathrm{G}_{\mathrm{O}} \alpha, \mathrm{G}_{\mathrm{q} / 11} \alpha, \mathrm{G} \beta$, and $\mathrm{G} \gamma$ between various subgroups of suicide subjects and normal controls were evaluated by 1-way analysis of variance (ANOVA). During analysis of the data, we included race as a potential confounding variable. Multiple comparisons were conducted and we report unadjusted $p$ values. We have indicated in the tables the Bonferroni adjusted $\alpha$ level and the rationale for its adjustment.

\section{RESULTS}

\section{Immunolabeling of G Protein Subunits in Prefrontal Cortex of Control and Suicide Subjects}

Representative autoradiograms of expressed levels of $G_{s} \alpha, G_{i 1} \alpha, G_{i 2} \alpha, G_{q / 11} \alpha, G_{O} \alpha$, and $G \beta \gamma$ subunits in the prefrontal cortex of control and suicide subjects are given in Figure 1. The molecular weights of $G_{i 1} \alpha, G_{i 2} \alpha$, $\mathrm{G}_{\mathrm{O}} \alpha$, and $\mathrm{G}_{\mathrm{q} / 11} \alpha$ were $42 \mathrm{kDa}$, which is consistent with those reported earlier by us (Dwivedi and Pandey 1997) and in the literature (Spiegel et al. 1990). It has been reported that $\mathrm{G}_{\mathrm{s}} \alpha$ resolves into two bands, i.e., 52 and 45 $\mathrm{kDa}$ (Jones et al. 1990), which is due to the splicing of a single gene (Robishaw et al. 1986). In our experiments, we also observed two bands (52 and $45 \mathrm{kDa}$ ); therefore both bands (low-molecular-weight $\mathrm{G}_{\mathrm{s}} \alpha_{-\mathrm{S}}$ and high-molecularweight $G_{s} \alpha_{-L}$ ) were quantified separately. Immunolabeling of G $\beta \gamma$ subunits using a common G $\beta \gamma$ antibody resolved into two bands: one at $35 \mathrm{kDa}(\beta)$ and another at $10 \mathrm{kDa}(\gamma)$. The apparent molecular weight of $\beta$-actin, which was used as a housekeeping protein, was $46 \mathrm{kDa}$.
Comparison studies showed that levels of $\mathrm{G}_{\mathrm{i} 2} \alpha$ and $\mathrm{G}_{\mathrm{O}} \alpha$ were significantly decreased and the level of $\mathrm{G}_{\mathrm{s}} \alpha_{-s}$ was significantly increased in BA 8/9 of suicide subjects $(n=43)$ compared with control subjects $(n=38)$ (Figure 2). No significant differences were observed in the levels of $G_{s} \alpha_{-L}, G_{q / 11} \alpha, G_{i 1} \alpha, G \beta$, or $G \gamma$ subunits between suicide and control subjects.

In order to examine if the levels of $G$ protein subunits were differentially affected in teenage and adult suicide, we subdivided the total suicide population into teenage ( $\leqslant 19$ years) and adult ( $\geqslant 20$ years) groups and analyzed the levels of $G$ protein subunits in these two populations separately. Representative Western blots of various subunits of $G$ proteins from two adult and two teenage suicide subjects and their respective agematched control subjects are shown in Figure 1, and scattergrams of protein levels of $G$ protein subunits from 27 adult suicide and 20 adult controls, and 16 teenage suicide and 18 teenage controls are given in Figures 3 and 4, respectively. It was observed that the expressed protein levels of $\mathrm{G}_{\mathrm{i} 2} \alpha$ and $\mathrm{G}_{\mathrm{O}} \alpha$ were significantly decreased whereas the protein level of $G_{s} \alpha_{-s}$ was significantly increased in BA $8 / 9$ of adult suicide subjects compared with adult control subjects. We did not observe any significant changes in protein levels of $\mathrm{G}_{\mathrm{s}} \alpha_{-\mathrm{L}}, \mathrm{G}_{\mathrm{i} 1} \alpha, \mathrm{G}_{\mathrm{q} / 11} \alpha, \mathrm{G} \beta$ or $\mathrm{G} \gamma$ subunits between adult control and adult suicide subjects (Figure 3 ).

When the teenage suicide group was compared with the teenage control group, there were no significant differences in protein levels of any of the $G$ protein subunits studied, i.e., $G_{s} \alpha_{-s} G_{s} \alpha_{-L}, G_{O} G_{i 1} G_{i 2} G_{q / 11} G \beta$, or $G \gamma$ (Figure 4).

\section{mRNA Levels of G Protein Subunits in Prefrontal Cortex of Suicide and Control Subjects}

In order to examine whether the altered protein levels of $G_{s} \alpha_{-S}, G_{i 2} \alpha$, and $G_{O} \alpha$ were due to an altered expression of their respective transcripts, we determined the mRNA levels of $G_{s} \alpha, G_{i 2} \alpha$, and $G_{O} \alpha$ subunits in the prefrontal cortex of control and suicide subjects using the 


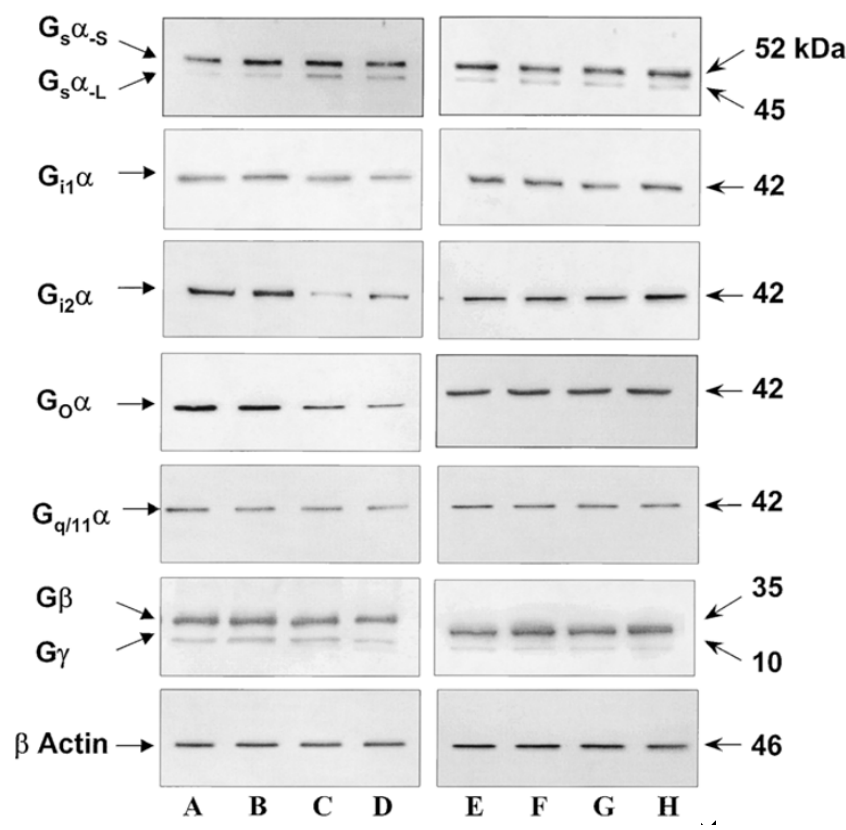

Figure 1. Representative western blots showing the immunolabeling of $G_{\mathrm{s}} \alpha_{-\mathrm{S}}, \mathrm{G}_{\mathrm{s}} \alpha_{-\mathrm{L}}, \mathrm{G}_{\mathrm{i} 1} \alpha, \mathrm{G}_{\mathrm{i} 2} \alpha, \mathrm{G}_{\mathrm{O}} \alpha, \mathrm{G}_{\mathrm{q} / 11} \alpha, \mathrm{G} \beta, \mathrm{G} \gamma$, and $\beta$ actin in BA $8 / 9$ of two adult suicide subjects $(C, D)$ and two matched adult control subjects $(\mathrm{A}, \mathrm{B})$, as well as two teenage suicide subjects $(\mathrm{G}, \mathrm{H})$, and two matched teenage control subjects $(\mathrm{E}, \mathrm{F})$. The ages of the adult suicide subjects (C and D) were 36 and 87 yrs, and PMI were 10 and $16 \mathrm{~h}$. Subject $C$ was female and subject $D$ was male. The psychiatric diagnosis in subject $C$ was major depression and subject $\mathrm{D}$ had adjustment and conduct disorder. The ages of the adult controls (A and B) were 37 and 83 yrs and PMI were 10 and $20 \mathrm{~h}$. The ages of the teenage suicide subjects ( $\mathrm{G}$ and $\mathrm{H})$ were 15 and 16 yrs and PMI were 11 and 20 h. Subject $G$ was female and subject $\mathrm{H}$ was male. Both subjects had no history of mental disorders. The ages of the teenage control subjects (E and F) were 16 and 17 yrs and PMI were 20 and $26 \mathrm{~h}$. Equal concentrations of protein samples $(25 \mu \mathrm{g})$ were subjected to $12 \%$ polyacrylamide gel electrophoresis and transferred to ECL-nitrocellulose membranes, which were then incubated with primary antibodies specific for $\mathrm{G}_{\mathrm{S}} \alpha, \mathrm{G}_{\mathrm{i} 1} \alpha, \mathrm{G}_{\mathrm{i} 2} \alpha$, $\mathrm{G}_{\mathrm{O}} \alpha, \mathrm{G}_{\mathrm{q} / 11} \alpha, \mathrm{G} \beta \gamma$, or $\beta$ actin, and secondary anti-rabbit or antimouse antibodies. The bands were quantified as described in Materials and Methods. The ratios of the optical densities of $\mathrm{G}_{\mathrm{s}} \alpha_{-\mathrm{S}}, \mathrm{G}_{\mathrm{i} 1} \alpha, \mathrm{G}_{\mathrm{i} 2} \alpha, \mathrm{G}_{\mathrm{O}} \alpha, \mathrm{G}_{\mathrm{q} / 11} \alpha, \mathrm{G} \beta$ and $\mathrm{G} \gamma$ to that of $\beta$ actin were calculated. Arrows indicate the molecular weights of $\mathrm{G} \alpha$ and $\beta \gamma$ subunits and $\beta$ actin.

quantitative RT-PCR technique. Although we observed that the protein level of $\mathrm{G}_{\mathrm{s}} \alpha_{-\mathrm{S}}$ but not $\mathrm{G}_{\mathrm{s}} \alpha_{-\mathrm{L}}$ was increased, during mRNA estimation we could not determine the levels of these two subunits separately because they are splice variants and show a high homology in DNA sequences. Further, because we observed that the protein level of only $G_{i 2} \alpha$ but not $G_{i 1} \alpha$ was altered in prefrontal cortex of suicide subjects, we measured the mRNA levels of both $G_{i 1} \alpha$ and $G_{i 2} \alpha$ subunits separately to ascertain whether the transcription of only one sub- type of $G_{i} \alpha$ protein, i.e. $G_{i 2} \alpha$, is changed. Figure 5 shows representative gel electrophoreses of the competitive RTPCR of $\mathrm{G}_{\mathrm{s}} \alpha$ (Figure 5, panel A), $\mathrm{G}_{\mathrm{i} 1} \alpha$ (Figure 5, panel C), $\mathrm{G}_{\mathrm{i} 2} \alpha$ (Figure 5, panel E), and $\mathrm{G}_{\mathrm{O}} \alpha$ (Figure 5, panel G) in prefrontal cortex from one control subject. We observed that amplification product arises from the $\mathrm{G}_{\mathrm{s}} \alpha$ mRNA template at $324 \mathrm{bp}$ and the corresponding digestion product from cRNA at $162+162 \mathrm{bp}$. Similarly, the amplification products for $G_{i 1} \alpha, G_{i 2} \alpha$, and $G_{O} \alpha$ were at 396 bp, $402 \mathrm{bp}$ and $312 \mathrm{bp}$, respectively, whereas the corresponding digestion products arising from cRNA for $\mathrm{G}_{\mathrm{i} 1} \alpha, \mathrm{G}_{\mathrm{i} 2} \alpha$, and $\mathrm{G}_{\mathrm{O}} \alpha$ were at $214+182,204+198$, and $161+152$, respectively. Representative competitive RTPCR analyses for $G_{\mathrm{s}} \alpha, G_{i 1} \alpha, G_{i 2} \alpha$, and $G_{O} \alpha$ are given in Figures 5, panels $B, D, F$, and $G$, respectively, where the point of equivalence represents the amount of mRNA for the respective $\mathrm{G}$ protein subunit.

As we observed with the protein levels, mRNA level of $G_{i 2} \alpha$ and $G_{O} \alpha$ were significantly decreased whereas $\mathrm{G}_{\mathrm{s}} \alpha$ was significantly increased in prefrontal cortex of suicide subjects as compared with control subjects, without any change in the mRNA level of $\mathrm{G}_{\mathrm{i} 1} \alpha$ (Figure 6).

When the suicide population was subdivided on the basis of age, we again observed that the mRNA levels of $G_{\mathrm{i} 2} \alpha$ and $G_{\mathrm{O}} \alpha$ were significantly decreased and $G_{\mathrm{s}} \alpha$ was significantly increased in prefrontal cortex of adult suicide subjects as compared with adult control subjects, without any change in mRNA levels of $G_{i 1} \alpha$ (Figure 7). On the other hand, there were no significant differences in mRNA levels of any of the $G$ protein subunits between our total teenage control and teenage suicide subjects (Figure 8).

\section{Effects of Potential Confounding Variables}

The effects of potential confounding variables such as $\mathrm{PMI}$, age, gender, and brain $\mathrm{pH}$ were evaluated with respect to mRNA and protein levels of $G$ protein subunits. During data analysis, race was included as a confounding variable, because of an uneven distribution in control and suicide populations. The PMI for suicide subjects and control subjects varied between 5 and $35 \mathrm{~h}$. Western blot analysis of expressed G protein levels in prefrontal cortex revealed that PMI had no significant effect on protein levels of $\mathrm{G}_{\mathrm{s}} \alpha_{-\mathrm{S}}(r=0.11, p=.32), \mathrm{G}_{\mathrm{s}} \alpha_{-\mathrm{L}}$ $(r=0.009, p=.93), \mathrm{G}_{\mathrm{i} 1} \alpha(r=0.10, p=.37), \mathrm{G}_{\mathrm{i} 2} \alpha(0.12, p=$ $.27), \mathrm{G}_{\mathrm{O}} \alpha(r=0.13, p=.26), \mathrm{G}_{\mathrm{q} / 11} \alpha(r=0.10, p=.37)$, $\mathrm{G} \beta(r=0.11, p=.32)$, or $\mathrm{G} \gamma(r=0.05, p=.67)$ subunits. Similarly, there was no effect of PMI on mRNA levels of $\mathrm{G}_{\mathrm{s}} \alpha(r=0.10, p=.36), \mathrm{G}_{\mathrm{i} 1} \alpha(r=0.12, p=.28), \mathrm{G}_{\mathrm{i} 2} \alpha(r=$ $0.10, p=.35)$ or $\mathrm{G}_{\mathrm{O}} \alpha(r=0.13, p=.22)$ subunit.

Correlation analysis between $\mathrm{pH}$ and protein levels of the various $\mathrm{G}$ protein subunits revealed no significant effects of $\mathrm{pH}$ on $\mathrm{G}_{\mathrm{s}} \alpha_{-\mathrm{S}}(r=0.09, p=.40), \mathrm{G}_{\mathrm{s}} \alpha_{-\mathrm{L}}(r=$ $0.03, p=.79), \mathrm{G}_{\mathrm{i} 1} \alpha(r=0.09, p=.41), \mathrm{G}_{\mathrm{i} 2} \alpha(r=0.06, p=$ $.58), \mathrm{G}_{\mathrm{O}} \alpha(r=0.03, p=.76), \mathrm{G}_{\mathrm{q} / 11} \alpha(r=0.02, p=.86)$, 


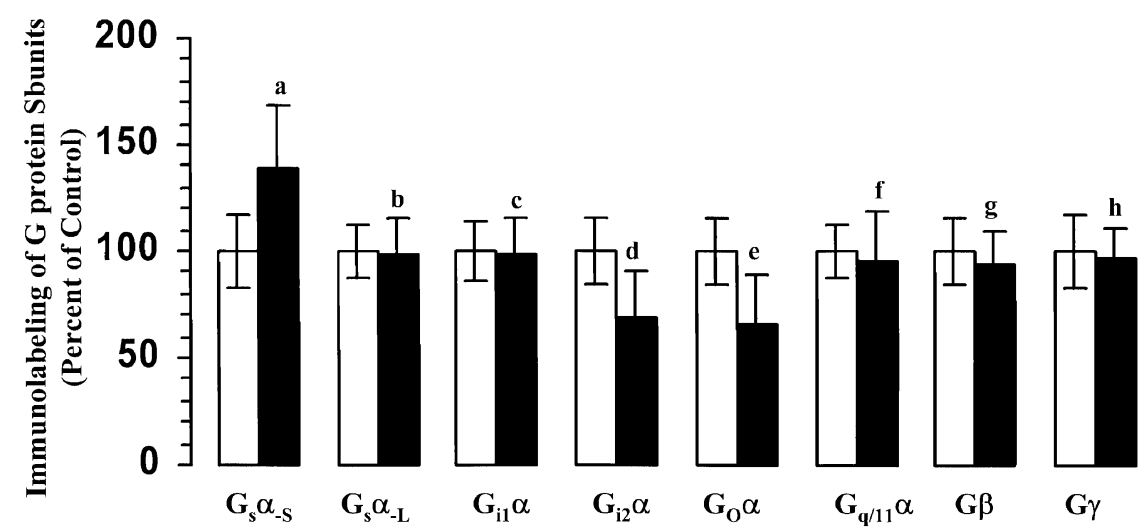

Figure 2. Immunolabeling of $G$ protein subunits in BA 8/9 of total control and total suicide subjects. Data are the mean \pm SD. Suicide group was compared with control group.

$$
\begin{aligned}
& { }^{a_{t}}=7.3, \mathrm{df}=79, p<.0001 \\
& { }^{{ }} \mathrm{t}=0.42, \mathrm{df}=79, p=.67 \\
& { }^{{ }}=0.48, \mathrm{df}=79, p=.63 \\
& { }^{d_{t}}=7.2, \mathrm{df}=79, p<.0001 \\
& { }^{{ }}=7.4, \mathrm{df}=79, p<.0001 \\
& \mathrm{f}_{\mathrm{t}}=1.05, \mathrm{df}=79, p=.29 \\
& \mathrm{~g}_{\mathrm{t}}=1.4, \mathrm{df}=79, p=.16 \\
& \mathrm{~h}_{\mathrm{t}}=0.75, \mathrm{df}=79, p=.45
\end{aligned}
$$

$\mathrm{G} \beta(r=0.04, p=.70)$, or $\mathrm{G} \gamma(r=0.07, p=.50)$ subunits. Similarly, $\mathrm{pH}$ did not affect mRNA levels of $\mathrm{G}_{\mathrm{s}} \alpha(\mathrm{r}=$ $0.09, p=.41), \mathrm{G}_{\mathrm{i} 1} \alpha(r=0.04, p=.73), \mathrm{G}_{\mathrm{i} 2} \alpha(r=0.19, p=$ $.07)$, or $\mathrm{G}_{\mathrm{O}} \alpha(r=0.04, p=.74)$ subunits. Since in some cases the $\mathrm{pH}$ was lower than 6.1, we subdivided the total population into those with $\mathrm{pH}<6.1$ and those with $\mathrm{pH}>$ 6.1. Comparison of the mRNA levels of $\mathrm{G}$ protein subunits revealed no significant differences between these two groups (data not shown).

There were 22 female and 59 male subjects in the total study population. Our correlation analysis showed that there were no significant effects of gender on protein levels of $\mathrm{G}_{\mathrm{s}} \alpha_{-\mathrm{S}}(r=0.15, p=.17), \mathrm{G}_{\mathrm{S}} \alpha_{-\mathrm{L}}(r=0.17, p=$ .13), $\mathrm{G}_{\mathrm{i} 1} \alpha(r=0.05, p=.65), \mathrm{G}_{\mathrm{i} 2} \alpha(r=0.11, p=.30), \mathrm{G}_{\mathrm{O}} \alpha$ $(r=0.14, p=.19), \mathrm{G}_{\mathrm{q} / 11} \alpha(r=0.10, p=.38), \mathrm{G} \beta(r=$ $0.07, p=.50)$ or $\mathrm{G} \gamma(r=0.11, p=.31)$ subunits. Similarly, gender did not affect mRNA levels of $\mathrm{G}_{\mathrm{s}} \alpha(r=$ $0.16, p=.45), \mathrm{G}_{\mathrm{i} 1} \alpha(r=0.04, p=.74), \mathrm{G}_{\mathrm{i} 2} \alpha(r=0.19, p=$ $.07)$ or $\mathrm{G}_{\mathrm{O}} \alpha(r=0.18, p=.11)$ subunits.

The ages of control and suicide subjects were in the range of 12-87 years. No significant correlation was observed between age and protein levels of $\mathrm{G}_{\mathrm{s}} \alpha_{-\mathrm{S}}(r=0.13$, $p=.23), \mathrm{G}_{\mathrm{s}} \alpha_{-\mathrm{L}}(r=0.02, p=.87), \mathrm{G}_{\mathrm{i} 1} \alpha(r=0.01, p=.92)$, $\mathrm{G}_{\mathrm{i} 2} \alpha(r=0.17, p=.14), \mathrm{G}_{\mathrm{O}} \alpha(r=0.18, p=.10), \mathrm{G} \beta(r=$
$0.20, p=.07)$ or $\mathrm{G} \gamma(r=0.14, p=.23)$ or between age and mRNA levels of $\mathrm{G}_{\mathrm{S}} \alpha(r=0.20, p=.07), \mathrm{G}_{\mathrm{i} 1} \alpha(r=$ $0.20, p=.07), \mathrm{G}_{\mathrm{i} 2} \alpha(r=0.17, p=.13)$ or $\mathrm{G}_{\mathrm{O}} \alpha(r=0.004, p=$ .97), however, immunolabeling of $\mathrm{G}_{\mathrm{q} / 11} \alpha$ was negatively correlated with age $(r=-0.44, p<.0001)$.

\section{Effects of Diagnosis and Antidepressant Treatment}

Since earlier studies found alterations in the levels of $G$ proteins in depressed suicide victims (Pacheco et al. 1996; Garcia-Sevilla et al. 1999), we also examined the effect of major depression on protein and mRNA levels of $\mathrm{G}$ protein subunits. For this purpose, we subdivided the adult suicide subjects into those who had a history of major depression and those who had a history of other psychiatric disorders. As mentioned in Methods, in the adult suicide group, 11 subjects had a history of major depression and 14 subjects had other psychiatric disorders (two had no mental illness)., The diagnoses of two suicide subjects were not available, so we excluded those two subjects from our analysis. When we analyzed the levels of $G$ protein subunits of the adult suicide subjects with a history of major depression and those with other mental disorders, both groups showed 


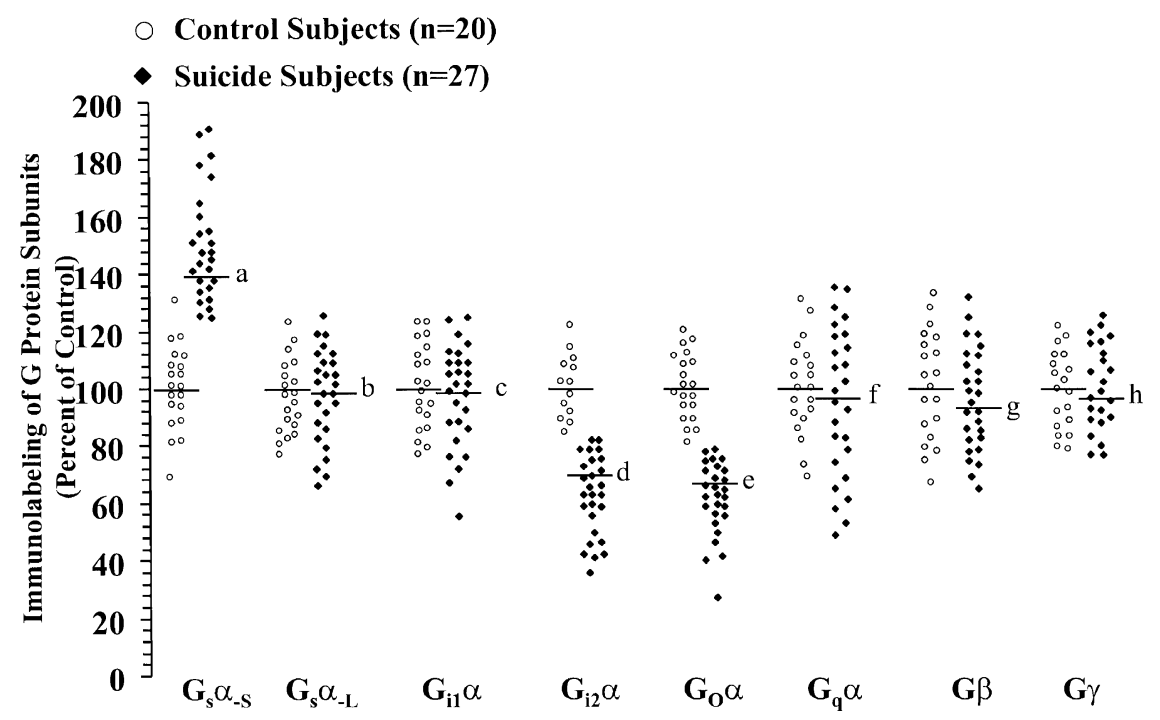

Figure 3. Scattergram of immunolabeling of $G$ protein subunits in BA 8/9 of adult control and adult suicide subjects. Adult suicide group was compared with adult control group.

$$
\begin{aligned}
& { }^{a} t=10.5, \mathrm{df}=45, p<.001 \\
& \mathrm{~b}_{\mathrm{t}}=0.35, \mathrm{df}=45, p=.73 \\
& \mathrm{c}_{\mathrm{t}}=0.58, \mathrm{df}=45, p=.56 \\
& \mathrm{~d}_{\mathrm{t}}=13, \mathrm{df}=45, p<.0001 \\
& \mathrm{e}_{\mathrm{t}}=14.06, \mathrm{df}=45, p<.0001 \\
& \mathrm{f}_{\mathrm{t}}=0.71, \mathrm{df}=45, p=.48 \\
& \mathrm{~g}_{\mathrm{t}}=0.88, \mathrm{df}=45, p=.38 \\
& \mathrm{~h}_{\mathrm{t}}=53, \mathrm{df}=45, p=.59
\end{aligned}
$$

significantly decreased levels of $G_{i 1} \alpha$ and $G_{O} \alpha$ and a significant increase in protein levels of $G_{S} \alpha_{-S}$ as compared with control subjects (Table 4). Similarly, the mRNA level of $G_{i 2} \alpha$ and $G_{O} \alpha$ significantly decreased and of $G_{s} \alpha$ was significantly increased in adult suicide subjects, both those with a history of major depression and those with a history of other mental disorders as compared with control subjects (Table 4). Interestingly, mRNA and protein levels of these $G$ protein subunits of the two suicide subjects who had no mental illness were similar to that of control subjects.

In view of previous studies showing that chronic administration of antidepressants may modify the levels of $G$ proteins in rat brain, we examined the effect of antidepressant toxicology on the levels of $G$ protein subunits. In the adult suicide population, four subjects showed positive antidepressant toxicology. The mean values of mRNA and protein levels of $G$ protein subunits were very similar between suicide subjects with positive antidepressant toxicology and suicide subjects with no antidepressant toxicology (data not shown).

To further examine whether the presence of psychopathology had any effect on the levels of G protein subunits in teenage suicide subjects, we subdivided teenage suicide subjects into those who had a history of psychiatric disorders and those who did not have a history of psychiatric disorders. The analysis of the effects of diagnosis on the levels of $\alpha$ subunits of $G$ proteins in teenage suicide subjects is given in Table 5 . In the teenage suicide group, seven subjects had no history of mental illnes and eight subjects had a history of mental illness. Interestingly, we observed that the protein level of $G_{i 2} \alpha$ and $G_{O} \alpha$ were significantly decreased and that the levels of $G_{s} \alpha_{-s}$ was significantly increased in those teenage suicide subjects who had a history of mental illness, both when compared with control subjects or with suicide subjects with no history of mental illness. On the other hand, the levels of these G protein subunits 


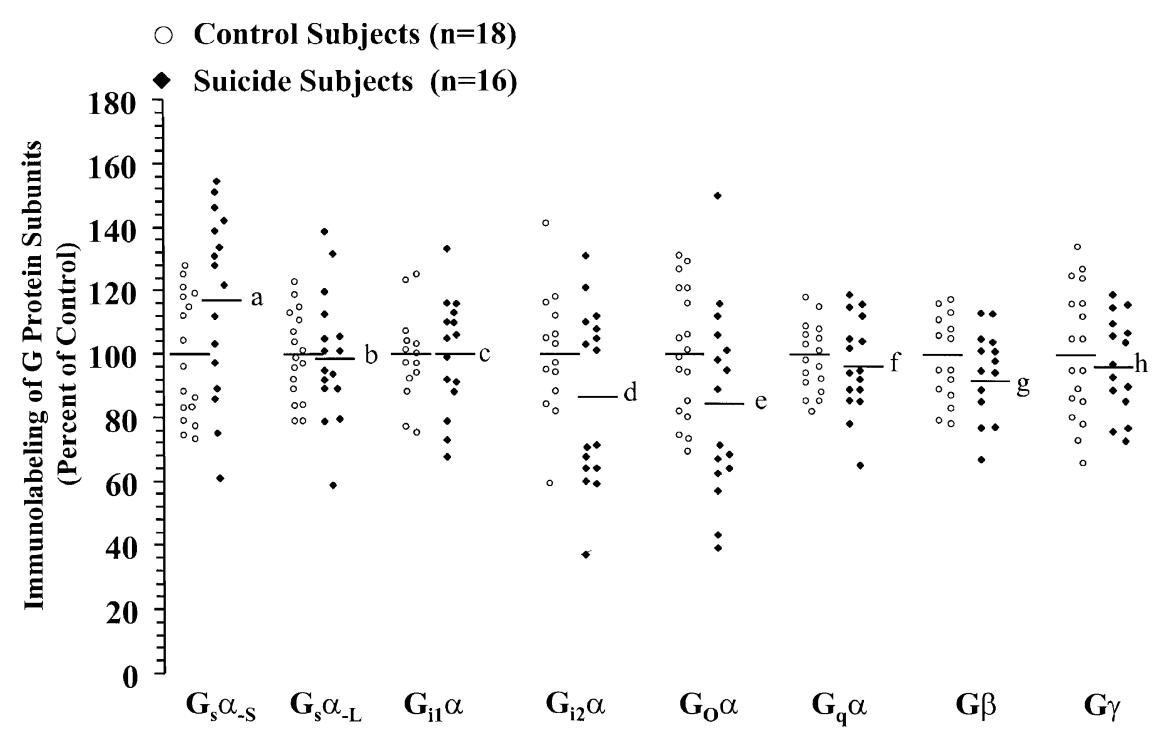

Figure 4. Scattergram of immunolabeling of G protein subunits in BA 8/9 of teenage control and teenage suicide subjects. Teenage suicide group was compared with teenage control group.

$$
\begin{aligned}
& { }^{a} t=1.9, \mathrm{df}=32, p=.06 \\
& \mathrm{~b}_{\mathrm{t}}=0.24, \mathrm{df}=32, p=.81 \\
& \mathrm{c}_{\mathrm{t}}=0.01, \mathrm{df}=32, p=.99 \\
& \mathrm{~d}_{\mathrm{t}}=1.76, \mathrm{df}=32, p=.87 \\
& \mathrm{e}_{\mathrm{t}}=1.9, \mathrm{df}=32, p=.07 \\
& \mathrm{f}_{\mathrm{t}}=0.89, \mathrm{df}=32, p=.38 \\
& \mathrm{~g}_{\mathrm{t}}=1.3, \mathrm{df}=32, p=.20 \\
& \mathrm{~h}_{\mathrm{t}}=0.53, \mathrm{df}=32, p=.59
\end{aligned}
$$

were not statistically different between teenage suicide subjects who had no history of mental illness and normal teenage control subjects. None of the subgroups of teenage suicide subjects showed any significant changes in the levels of $G_{s} \alpha_{-L}, G_{q / 11} \alpha$, or $G \beta$ or $G \gamma$ subunits compared with control subjects. Out of eight teenage suicide subjects who had a history of psychiatric disorders, three showed positive antidepressant toxicology. The mean values of mRNA and protein levels of $G$ protein subunits from those suicide subjects who showed positive antidepressant toxicology were similar to those suicide subjects who did not show positive antidepressant toxicology (data not shown).

\section{DISCUSSION}

The present study revealed several interesting observations in the prefrontal cortex of suicide subjects: (1) pro- tein levels of $\mathrm{G}_{\mathrm{i} 2} \alpha$ and $\mathrm{G}_{\mathrm{O}} \alpha$ were significantly decreased, whereas that of $G_{s} \alpha_{-s}$ was significantly increased; (2) no changes were observed in protein levels of $\mathrm{G}_{\mathrm{s}} \alpha_{-\mathrm{L}}, \mathrm{G}_{\mathrm{q} / 11} \alpha$, $\mathrm{G}_{\mathrm{i} 1} \alpha, \mathrm{G}_{\beta}$ and $\mathrm{G}_{\gamma}$ subunits; (3) changes in protein levels of $\mathrm{G}_{\mathrm{i} 2} \alpha, \mathrm{G}_{\mathrm{O}} \alpha$, and $\mathrm{G}_{\mathrm{s}} \alpha_{-s}$ were accompanied by parallel changes in their respective mRNA levels; (4) changes in the expression of $G_{i 2} \alpha, G_{O} \alpha$, and $G_{s} \alpha-s$ were present in all adult suicide subjects who had a history of mental disorders; (5) no significant changes in the expression of G protein subunits were observed when teenage suicide subjects were compared with teenage control subjects; however, expression of $G_{i 2} \alpha$ and $G_{\mathrm{O}} \alpha$ was significantly decreased and expression of $G_{s} \alpha_{-s}$ was significantly increased in those teenage suicide subjects who had a history of mental disorders.

In the past, there have been a few studies examining expression levels of $\mathrm{G}$ protein subunits by the immunolabeling technique in the postmortem brain of suicide subjects. For example, Cowburn et al. (1994) reported 

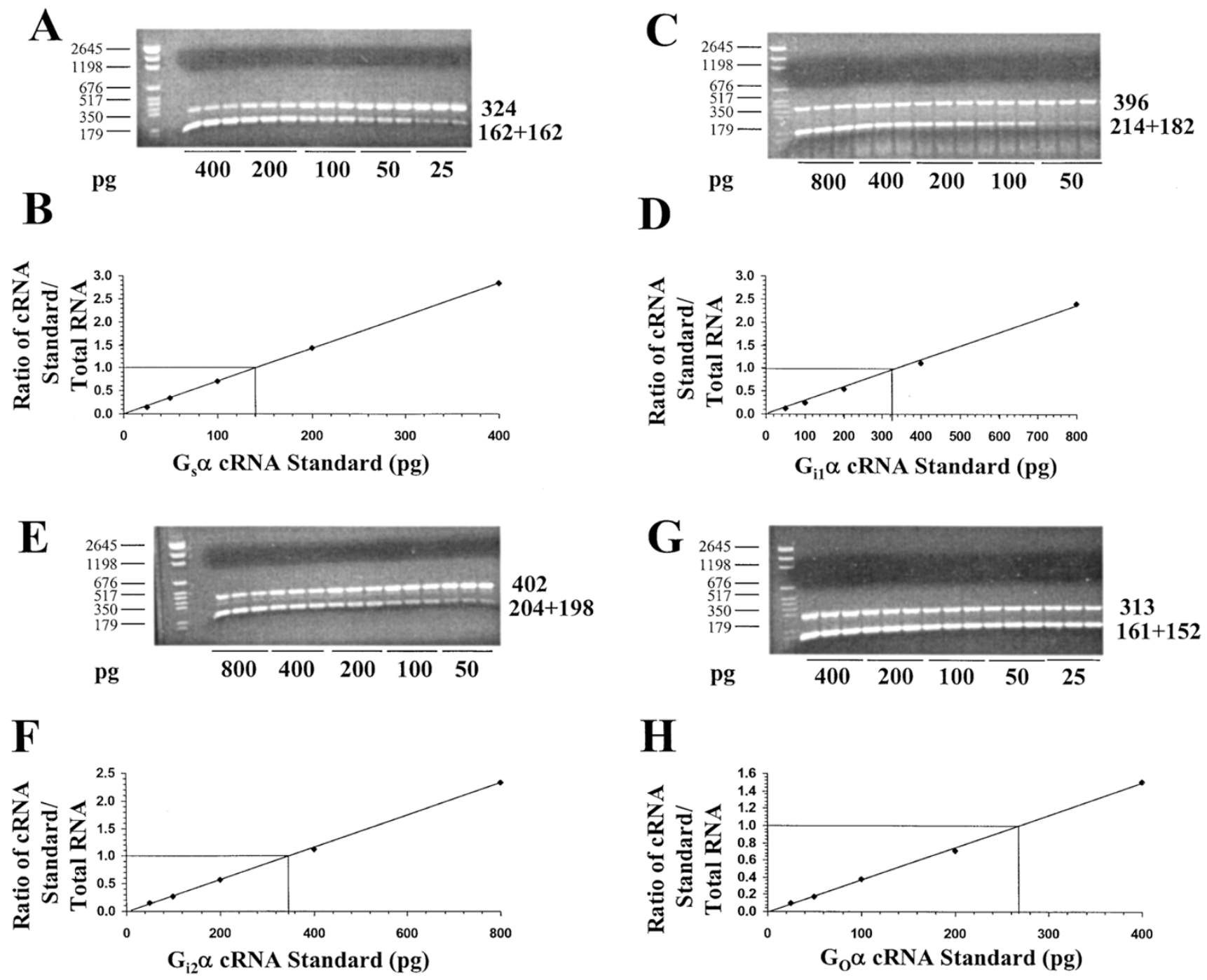

Figure 5. Representative experiments showing competitive PCR analysis for $G_{s} \alpha(A), G_{i 1} \alpha(C), G_{i 2} \alpha(E)$, and $G_{O} \alpha(G)$ mRNA contents in BA 8/9 obtained from one control subject. Decreasing concentrations of corresponding cRNAs were added to $1 \mu \mathrm{g}$ of total RNA. The mixtures were reverse transcribed and PCR-amplified in the presence of trace amounts of $\left[{ }^{32} \mathrm{P}\right] \mathrm{dCTP}$; aliquots were digested by $B g l \mathrm{II}$ (for $\mathrm{G}_{\mathrm{s}} \alpha$ and $\mathrm{G}_{\mathrm{i} 2} \alpha$ ) or XhoI (for $\mathrm{G}_{\mathrm{il}} \alpha$ and $\mathrm{G}_{\mathrm{O}} \alpha$ ) and electrophoresed on $1.5 \%$ agarose gel. The higher molecular size bands correspond to the amplification products arising from mRNA, whereas the lower bands arise from cRNA generated from the internal standard digested by $B g l \mathrm{II}$ or XhoI. Data derived from agarose gels were plotted as the counts incorporated into the amplified cRNA standard divided by the counts incorporated into the corresponding subunit mRNA amplification product verses the known amount of internal standard cRNA added to the test sample. The point of equivalence represents the amount of $G_{s} \alpha(B), G_{i 1} \alpha(D), G_{i 2} \alpha(F)$, or $G_{O} \alpha(H) m R A$

an increase in the immunolabeling of $G_{s} \alpha_{-S}$ in frontal cortex of suicide subjects without any change in $G_{s} \alpha_{-L}$, or $G_{i 1 / 2} \alpha$ protein. In the prefrontal cortex (BA 8/9) of depressed suicide, Pacheco et al. (1996) reported an increase in the immunolabeling of $\mathrm{G}_{\mathrm{s}} \alpha_{-S}$ and a decrease in that of $\mathrm{G}_{\mathrm{i} 2} \alpha$. Contrary to that, Garcia-Sevilla et al. (1999) reported an increase in the immunolabeling of $\mathrm{G}_{\mathrm{i} 1 / 2} \alpha$ in prefrontal cortex (BA 9) of suicide subjects. In the present study, we found that not only the immunolabeling of $G_{s} \alpha_{-s}$ is increased and that of $G_{i 2} \alpha$ and $G_{O} \alpha$ is decreased, but that their respective mRNA levels are also altered in a parallel direction, which suggests that there are defects in the transcription of these genes in prefrontal cortex of suicide subjects. Our finding of an increased expression of $G_{s} \alpha_{-s}$ is thus consistent with that of Cowburn et al. (1994) and Pacheco et al. (1996). On the other hand, contrary to the reports of GarciaSevilla et al. (1999) but similar to Pacheco et al. (1996), we found decreased expression specifically of only $\mathrm{G}_{\mathrm{i} 2} \alpha$, without any change in $\mathrm{G}_{\mathrm{i} 1} \alpha$. Additionally, we found decreased expression of $G_{O} \alpha$ protein in prefrontal cortex of suicide subjects, which is contrary to the re- 
Control Subjects $(n=38)$

Suicide Subjects $(n=43)$
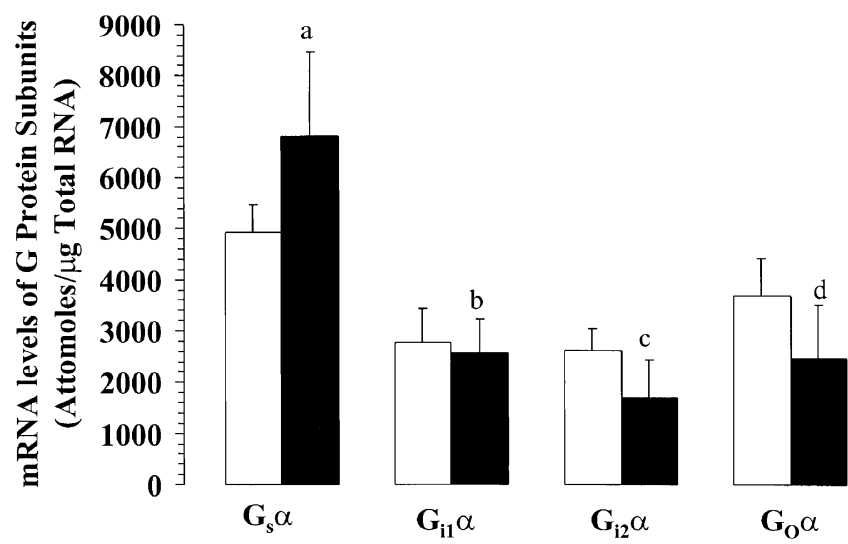

Figure 6. mRNA levels of G protein subunits in BA 8/9 of total control and total suicide subjects. Data are the mean \pm SD Suicide group was compared with control group.

$$
\begin{aligned}
& { }^{a} t=6.7, d f=79, p<.0001 \\
& { }^{b_{t}}=1.35, \text { df }=79, p=.18 \\
& { }^{c}=7.2, d f=79, p<.0001 \\
& { }^{d_{t}}=7.4, d f=79, p<.0001
\end{aligned}
$$

port of Pacheco et al. (1996), who did not find any significant change in the expression of this $G$ protein subunit in prefrontal cortex of depressed suicide subjects. The reasons behind these discrepancies between our results and those of other investigators are not clear; however, this cannot be attributed to the brain area studied, since all these studies were performed in the prefrontal cortex (BA 8/9). The differences in the methodology used in determining the levels of $G$ protein subunits cannot be ruled out. It is worth mentioning that we found differences in the expression of selective $G$ protein subunits both at the transcriptional and the translational level, thus ruling out the possibility of any artifact.

The observed changes do not appear to be related to potential confounding variables such as age, gender, race, $\mathrm{PMI}$, or $\mathrm{pH}$ of the brain, as these variables did not show any effects on mRNA or protein levels of G protein subunits, with the single exception that mRNA and protein levels of the $G_{q / 11} \alpha$ subunit were negatively correlated with age. It is pertinent to mention that there are two reports on the effects of age on expression levels of $G$ protein subunits. Li et al. (1996) reported that levels of $G_{q / 11} \alpha$ and $G_{O} \alpha$ are decreased with an increase in age, whereas Young et al. (1991) found that the immunoreactivity of $\mathrm{G}_{\mathrm{i}} \alpha$ is decreased in the parietal cortex af-
Control Subjects $(\mathbf{n}=\mathbf{2 0})$

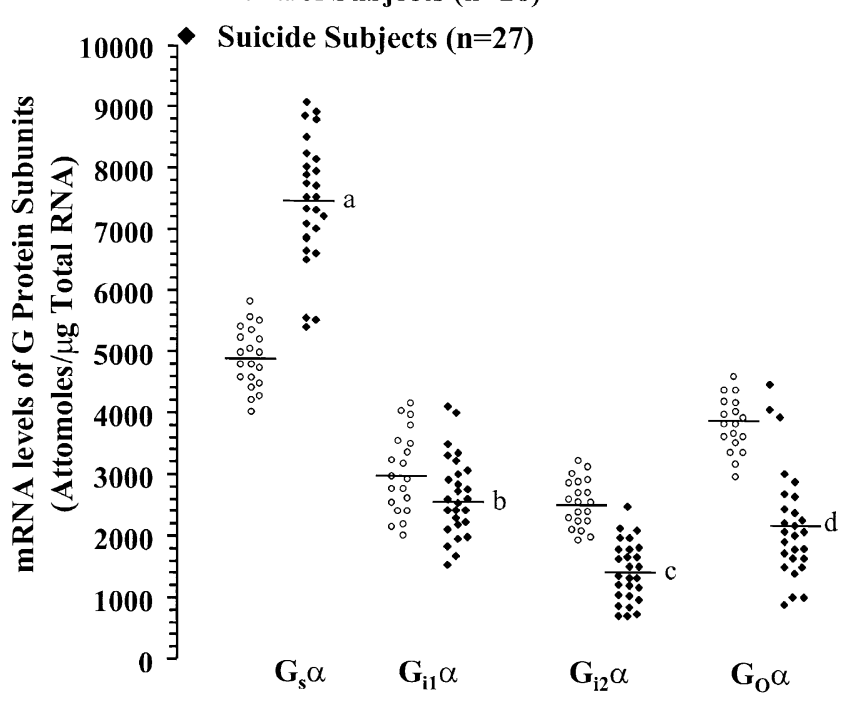

Figure 7. Scattergram of mRNA levels of $G$ protein subunits in BA $8 / 9$ of adult control and adult suicide subjects. Adult suicide group was compared with adult control group.

${ }^{\mathrm{a}} \mathrm{t}=10.7, \mathrm{df}=45, p<.0001$

$\mathrm{b}_{\mathrm{t}}=1.9, \mathrm{df}=45, p=.06$

${ }^{c} \mathrm{t}=10.1, \mathrm{df}=45, p<0.001$

$\mathrm{d}_{\mathrm{t}}=7.6, \mathrm{df}=45, p<.0001$

ter the age of 40 years, and also that levels of $G_{O} \alpha$ and $\mathrm{G}_{\mathrm{q} / 11} \alpha$ proteins are inversely correlated with age in the prefrontal cortex. In our study population, the age range was between 12 and 87 years, and as reported by Li et al. (1996), we found decreased mRNA and protein levels of $\mathrm{G}_{\mathrm{q} / 11} \alpha$ protein with an increase in age; however, contrary to this report, we did not observe any significant effects of age on $\mathrm{G}_{\mathrm{O}} \alpha$ proteins. Moreover, we did not observe any significant effects of age on $\mathrm{G}_{\mathrm{i}} \alpha$ proteins, as observed by Young et al. (1991).

An interesting aspect of our study was the inclusion of a teenage suicide population. As mentioned at the beginning of this article, it has been suggested that some factors associated with teenage suicide may be different from those of adult suicide. For example, teenage suicide is driven primarily by impulsive, aggressive and violent behaviors. There is an age related decline in aggressivity (Mann et al. 1989), but there is increased seriousness of suicidal behavior with an increase in age. Brent et al. (1993) reported that teenage suicide completers had more impulsive and aggressive personality disorders and higher aggression ratings than controls. Apter et al. (1995) also reported that adolescents with aggression and conduct disorders may be suicidal even in the absence of depression. In contrast, most of the 


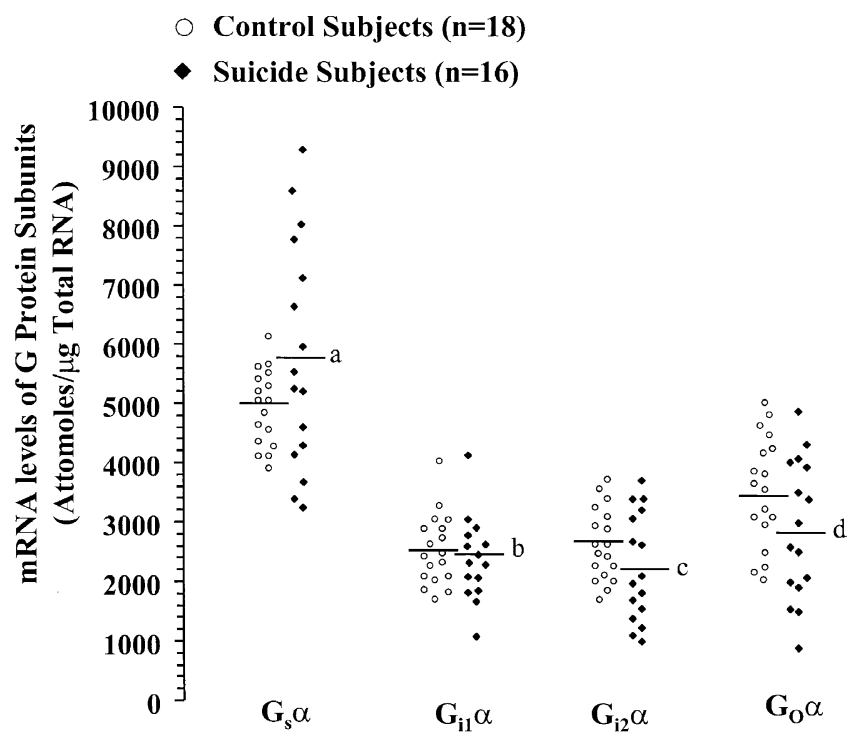

Figure 8. Scattergram of mRNA levels of $G$ protein subunits in BA 8/9 of teenage control and teenage suicide subjects. Teenage suicide group was compared with teenage control group.

${ }^{\mathrm{a}} \mathrm{t}=1.6, \mathrm{df}=32, p=.12$

$\mathrm{b}_{\mathfrak{t}}=0.27, \mathrm{df}=32, p=.79$

${ }^{c} \mathrm{t}=1.9, \mathrm{df}=32, p=.07$

$\mathrm{d}_{\mathrm{t}}=1.7, \mathrm{df}=32, p=.09$

adult suicide subjects have a history of some form of mental illness. Thus it is interesting to examine whether there are any differences in altered expression of $G$ protein subunits between teenage and adult suicide subjects. As mentioned above, we found that in prefrontal cortex of suicide victims, expression of $\mathrm{G}_{\mathrm{s}} \alpha_{-S}$ is increased and of $\mathrm{G}_{\mathrm{i} 2} \alpha$ and $\mathrm{G}_{\mathrm{O}} \alpha$ is decreased. When the total suicide population was subdivided into teenage and adult groups, interestingly, it was observed that the expression of $G$ protein subunits remained unaltered in teenage suicide subjects as compared with age-matched teenage control subjects. On the other hand, adult suicide subjects showed a significant increase in the expression of $G_{s} \alpha_{-s}$ and a significant decrease in the expression of $G_{i 2} \alpha$ and $G_{O} \alpha$ as compared with agematched adult control subjects. More interestingly, when the teenage suicide population was subdivided into those who had a history of mental disorders and those who did not have mental disorders, the expression of $G_{s} \alpha_{-s}$ was increased and the expression of $G_{i 2} \alpha$ and $G_{O} \alpha$ was decreased in those teenage suicide subjects who had a history of mental disorders. Similarly, the levels of $G$ protein subunits were unchanged in those adult suicide subjects who did not have a mental disorder, although the number of subjects in this group was too small for a meaningful conclusion. However, the levels of $G_{s} \alpha_{-S}, G_{i 2} \alpha$, and $G_{O} \alpha$ were altered in those adult suicide subjects who had a history of major depression or other psychiatric disorders. This suggests that the alterations in levels of specific $G$ protein subunits are related to mental disorders rather than suicide per se, or even whether it is adult or teenage suicide.

What could be the molecular mechanisms underlying the altered expression of $G_{s} \alpha_{-s}, G_{i 2} \alpha$, and $G_{O} \alpha$ in prefrontal cortex of suicide subjects remains to be elucidated. In the past, several studies have demonstrated that the numbers of $5 \mathrm{HT}_{1 \mathrm{~A}}, 5 \mathrm{HT}_{2 \mathrm{~A}}, \alpha_{1^{-}}, \alpha_{2^{-}}$, and $\beta$ adrenergic receptors are altered in postmortem brain of suicide subjects (reviewed by Gross-Isseroff et al. 1998; Pandey et al. 2002). These receptors utilize different signaling mechanisms coupled to various $G$ proteins to mediate their responses. $5 \mathrm{HT}_{2 \mathrm{~A}}$ and $\alpha_{1}$-adrenergic receptors are linked to the phosphoinositide signal transduction system via the $\mathrm{G}_{\mathrm{q} / 11} \alpha$ subunit, whereas $5 \mathrm{HT}_{1 \mathrm{~A}}$ and $\alpha_{2}$-adrenergic receptors are linked to the adenylyl cyclase-cAMP signaling system via $G_{i} \alpha$ and $G_{O} \alpha$ subunits. On the other hand, $\beta$ adrenergic receptors are linked to the adenylyl cyclase-cAMP signaling system via $G_{s} \alpha$ in a stimulatory fashion. It has been reported that many $G$ protein-coupled receptors display the property of desensitization, which is the waning of signaling during continuous activation by agonists (Liggett 1997). This long-term agonist promoted-desensitization causes decreased expression of cellular $G$ proteins. Such changes in levels of $\alpha$ subunits of $G_{s}, G_{i}$, and $G_{11}$ have been reported earlier (Milligan et al. 1995). Although the concept is speculative in nature, it is quite possible, that continuous stimulation of receptors such as $5 \mathrm{HT}_{1 \mathrm{~A}}$ and $\alpha_{2}$-adrenergic receptors, as reported in postmortem brain of suicide subjects, may possibly be causing decreased expression of $G_{i} \alpha$ and $G_{O} \alpha$ as part of the desensitization. On the other hand, the mechanism of increased expression of $\mathrm{G}_{\mathrm{s}} \alpha_{-\mathrm{S}}$ in prefrontal cortex of suicide victims, where increased binding to $\beta$ adrenergic receptors has been shown, cannot be explained on the basis of agoniststimulated desensitization. Similarly, expression of the $\mathrm{G}_{\mathrm{q} / 11} \alpha$ subunit is not altered even though the $5 \mathrm{HT}_{2 \mathrm{~A}}$ receptors coupled to this $\mathrm{G}$ protein subunit are upregulated in postmortem brain of suicide victims (Pandey et al. 2002; Gross-Isseroff et al. 1998). It is quite possible that the expression of $G$ protein subunits is independent of receptor stimulation. The complexity of these signaling system is further illustrated by studies that demonstrate that the same effector can switch to different $G$ protein subunits through the agonist-mediated phosphorylation of receptors by kinases such as protein kinase A (Daaka et al. 1997; Lefkowitz 1998; Luo et al. 1999; Lawler et al. 2001). On the other hand, interestingly, in cells expressing different receptors that couple to the same $G$ protein, a $G$ protein downregulation of one receptor but not the other has also been reported (McKenzie et al. 1991). Thus, the regulation of expres- 
Table 4. Effect of mental Disorders on Protein and mRNA Levels of G Protein Subunits in Prefrontal Cortex of Adult Control and Adult Suicide

\begin{tabular}{|c|c|c|c|c|c|c|c|c|c|c|c|c|}
\hline \multirow[b]{3}{*}{ Variables } & \multirow{2}{*}{\multicolumn{2}{|c|}{$\begin{array}{c}\text { Control } \\
\text { subjects } \\
(\mathrm{n}=20) \\
1\end{array}$}} & \multicolumn{4}{|c|}{ Suicide victims $*(n=25)$} & & & & & & \\
\hline & & & $\begin{array}{r}\text { With a } \\
\text { of } \\
\text { depr } \\
\text { (n }\end{array}$ & $\begin{array}{l}\text { story } \\
\text { or } \\
\text { ion } \\
\text { 1) }\end{array}$ & \multicolumn{2}{|c|}{$\begin{array}{l}\text { With a history } \\
\text { of other } \\
\text { psychiatric } \\
\text { disorders } \\
(\mathrm{n}=14) \\
3\end{array}$} & \multicolumn{3}{|c|}{ Overall ANOVA } & \multicolumn{3}{|c|}{ Multiple comparison $^{\dagger}$} \\
\hline & Mean & SD & Mean & SD & Mean & SD & df & F & $\mathbf{P}$ & 1 vs 2 & 1 vs 3 & 2 vs 3 \\
\hline \multicolumn{13}{|c|}{ Protein levels ${ }^{\mathbb{I}}$} \\
\hline $\mathrm{G}_{\mathrm{s}} \alpha_{-\mathrm{S}}$ & 100 & 14 & 160 & 19 & 144 & 14 & 2,42 & 64.85 & $<.0001$ & $<.0001$ & $<.0001$ & .02 \\
\hline $\mathrm{G}_{\mathrm{s}} \alpha_{-\mathrm{L}}$ & 100 & 11 & 98 & 15 & 101 & 18 & 2,42 & 0.18 & .83 & .69 & .79 & .54 \\
\hline $\mathrm{G}_{\mathrm{i} 1} \alpha$ & 100 & 15 & 101 & 16 & 90 & 17 & 2,42 & 1.8 & .16 & .77 & .10 & .09 \\
\hline $\mathrm{G}_{\mathrm{i} 2} \alpha$ & 100 & 11 & 61 & 9 & 56 & 12 & 2,42 & 82.93 & $<.0001$ & $<.0001$ & $<.0001$ & .19 \\
\hline $\mathrm{G}_{\mathrm{O}} \alpha$ & 100 & 11 & 55 & 10 & 60 & 9 & 2,42 & 95.97 & $<.0001$ & $<.0001$ & $<.0001$ & .22 \\
\hline $\mathrm{G}_{\mathrm{q} / 11} \alpha$ & 100 & 16 & 101 & 24 & 91 & 27 & 2,42 & 0.98 & .38 & .9 & .22 & .24 \\
\hline $\mathrm{G}_{\beta}$ & 100 & 18 & 93 & 16 & 98 & 18 & 2,42 & 0.51 & .60 & .32 & .85 & .45 \\
\hline $\mathrm{G}_{\gamma}$ & 100 & 13 & 101 & 14 & 93 & 14 & 2,42 & 1.52 & .23 & .73 & .15 & .12 \\
\hline \multicolumn{13}{|l|}{ mRNA $^{\S}$} \\
\hline $\mathrm{G}_{\zeta} \alpha$ & 4907 & 368 & 7201 & 1085 & 7623 & 1015 & 2,42 & 54.61 & $<.0001$ & $<.001$ & $<.001$ & .20 \\
\hline $\mathrm{G}_{\mathrm{i} 1} \alpha$ & 3018 & 642 & 2811 & 637 & 2593 & 634 & 2,42 & 1.83 & .17 & .39 & .006 & .40 \\
\hline $\mathrm{G}_{\mathrm{i} 2} \alpha$ & 2562 & 349 & 1332 & 321 & 1452 & 462 & 2,42 & 51.86 & $<.0001$ & $<.0001$ & $<.0001$ & .44 \\
\hline $\mathrm{G}_{\mathrm{O}} \alpha$ & 3878 & 408 & 2182 & 880 & 2330 & 984 & 2,42 & 25,96 & $<.0001$ & $<.0001$ & $<.0001$ & .63 \\
\hline
\end{tabular}

${ }^{*}$ In two cases, psychiatric diagnosis was not available. ${ }^{9}$ Percent of control; ${ }^{\S}$ Attomoles $/ \mu \mathrm{g}$ total RNA; ${ }^{\dagger}$ For multiple comparison, the $p$ values were compa ccompared with a Bonferroni adjusted $\alpha=.05 / 12=.004$. Multiple comparison test with $p<.004$ was considered significant.

sion of $\mathrm{G}$ proteins appears to be quite complex and needs further investigation.

The pathophysiological significance of the differences in levels of $G_{s} \alpha_{-s}, G_{i 2} \alpha$, and $G_{O} \alpha$ proteins found in the prefrontal cortex of suicide subjects and control subjects is currently not known. However, the alterations in expression of $G_{s} \alpha_{-S}, G_{i} \alpha$, and $G_{O} \alpha$ have significant functional importance because many receptors modulate their responses through the activation of these $G$ proteins, which then activate or inhibit various effectors. These effectors regulate cell functions through the production of second messengers, which then lead to the phosphorylation of various membrane and cytosolic proteins, which not only induce intracellular instantaneous reactions, like neuronal excitability and secretion of hormones, but also lead to the regulation of gene expression by activating a variety of transcription factors. It has been suggested that even small alterations in levels of $G$ protein may lead to a manyfold amplification of signal transduction (Ross 1989). In our study, we found that the expression of $G_{s} \alpha_{-s}$, which is more effectively coupled to adenylyl cyclase in a stimulatory fashion than $G_{s} \alpha_{-L}$ (Walseth et al. 1989), is increased and that of $G_{12} \alpha$ and $G_{O} \alpha$ is decreased in prefrontal cortex of suicide subjects, which suggests the activation of adenylyl cyclase and therefore increased formation of cAMP in suicide brain. On the other hand, $\mathrm{G}_{\mathrm{O}} \alpha$ is the most abundant heterotrimeric $\mathrm{G}$ protein in mammalian brain, and one of its primary functions is the regulation of several ion channels (Gilman 1987). A decrease in the expression of $G_{O} \alpha$ protein indicates abnormal $G$ protein-mediated regulation of ion channels in prefrontal cortex of suicide subjects. Interestingly, it has been reported that antidepressants cause a decrease in the levels of cyclic AMP (reviewed by Manji 1992), and chronic administration of antidepressants to rats causes a decrease in the level of $\mathrm{G}_{\mathrm{s}} \alpha$ protein in brain (Lesch and Manji 1992). Thus, our present study, which shows that the levels of $G_{i 2 \alpha}$ and $G_{O} \alpha$ are decreased and of $G_{s} \alpha_{-S}$ are increased in the postmortem brains of those suicide subjects who had a history of mental illness, together with observations by other investigators that psychoactive drugs cause changes in the levels of $G$ proteins that are directly the opposite of our observations, suggests that these alterations in $\mathrm{G}_{\mathrm{s}} \alpha_{-\mathrm{s}}, \mathrm{G}_{\mathrm{i} 2 \alpha}$, and $\mathrm{G}_{\mathrm{O}} \alpha$ proteins may have an important role in the pathophysiology of mental disorders.

In summary, this is the first study to examine mRNA and protein expression of various subunits of $G$ proteins in postmortem brain of teenage and adult suicide subjects with and without mental disorders, and it suggests that expression of $G_{O} \alpha$ and $G_{i 2} \alpha$ is decreased and that of $\mathrm{G}_{\mathrm{s}} \mathrm{\alpha}_{-\mathrm{S}}$ is increased in suicide subjects. These changes were present in all adult suicide subjects who had a history of mental disorders. Although we did not observe any significant differences in the levels of $\alpha$ subunits of $G$ proteins in the total teenage suicide population, we found that the expression of $G_{i 2 \alpha}$ and $G_{O} \alpha$ was decreased and 
Table 5. Effect of Mental Disorders on mRNA and Protein Levels of G Protein Subunits in Prefrontal Cortex of Teenage Control and Teenage Suicide Victims

\begin{tabular}{|c|c|c|c|c|c|c|c|c|c|c|c|c|}
\hline \multirow[b]{3}{*}{ Variables } & \multirow{2}{*}{\multicolumn{2}{|c|}{$\begin{array}{c}\text { Control } \\
\text { subjects } \\
(n=18) \\
1\end{array}$}} & \multicolumn{5}{|c|}{ Suicide victims $(\mathrm{n}=15)^{*}$} & & & & & \\
\hline & & & \multicolumn{4}{|c|}{$\begin{array}{l}\text { With no } \\
\text { history of } \\
\text { psychiatric } \\
\text { disorders } \\
(n=7) \\
3\end{array}$} & \multicolumn{3}{|c|}{ Overall ANOVA } & \multicolumn{3}{|c|}{ Multiple comparison $^{+}$} \\
\hline & Mean & SD & Mean & SD & Mean & SD & df & $\mathbf{F}$ & $p$ & 1 vs 2 & 1 vs 3 & 2 vs 3 \\
\hline \multicolumn{13}{|c|}{ Protein levels ${ }^{\mathbb{I}}$} \\
\hline $\mathrm{G}_{\mathrm{s}} \alpha_{-\mathrm{S}}$ & 100 & 20 & 135 & 21 & 98 & 22 & 2,30 & 8.8 & .001 & $<.0001$ & .82 & .002 \\
\hline $\mathrm{G}_{\mathrm{s}} \alpha_{-\mathrm{L}}$ & 100 & 14 & 101 & 25 & 95 & 15 & 2,30 & 0.29 & .75 & .87 & .51 & .48 \\
\hline $\mathrm{G}_{\mathrm{i} 1} \alpha$ & 100 & 15 & 102 & 11 & 101 & 23 & 2,30 & 0.03 & .96 & .81 & .86 & .97 \\
\hline $\mathrm{G}_{\mathrm{i} 2} \alpha$ & 100 & 18 & 60 & 10 & 112 & 10 & 2,30 & 26.48 & $<.0001$ & $<.0001$ & .07 & $<.0001$ \\
\hline $\mathrm{G}_{\mathrm{O}} \alpha$ & 100 & 21 & 59 & 12 & 108 & 21 & 2,30 & 15.96 & $<.0001$ & $<.0001$ & .35 & $<.0001$ \\
\hline $\mathrm{G}_{\mathrm{q} / 11} \alpha$ & 100 & 11 & 101 & 12 & 89 & 17 & 2,30 & 2.34 & .11 & .81 & .06 & .07 \\
\hline $\mathrm{G}_{\beta}$ & 100 & 14 & 94 & 16 & 95 & 10 & 2,30 & 0.46 & .64 & .42 & .48 & .96 \\
\hline $\mathrm{G}_{\gamma}$ & 100 & 21 & 94 & 17 & 98 & 14 & 2,30 & 0.25 & .78 & .49 & .79 & .73 \\
\hline \multicolumn{13}{|l|}{ mRNA $^{\S}$} \\
\hline $\mathrm{G}_{S} \alpha$ & 4964 & 661 & 7074 & 1876 & 4319 & 815 & 2,30 & 14.1 & $<.0001$ & $<.0001$ & .19 & $<.0001$ \\
\hline $\mathrm{G}_{\mathrm{i} 1} \alpha$ & 2506 & 579 & 2516 & 864 & 2456 & 505 & 2,30 & 0.02 & .98 & .97 & .86 & .86 \\
\hline $\mathrm{G}_{\mathrm{i} 2} \alpha$ & 2675 & 524 & 1433 & 316 & 2928 & 506 & 2,30 & 23.40 & $<.0001$ & $<.0001$ & .25 & $<.0001$ \\
\hline $\mathrm{G}_{\mathrm{O}} \alpha$ & 2499 & 928 & 1948 & 704 & 3711 & 767 & 2,30 & 10.99 & $<.0001$ & $<.0001$ & .57 & $<.0001$ \\
\hline
\end{tabular}

${ }^{*}$ In one case the diagnosis was not available; ${ }^{\text {TPercent }}$ of control; ${ }^{\S}$ Attomoles $/ \mu g$ total RNA; ${ }^{\dagger}$ For multiple comparison, the $p$ values were compared with a Bonferroni adjusted $\alpha=.05 / 12=.004$. Multiple comparison test with $p<.004$ was considered significant.

that of $G_{s} \alpha_{-s}$ was increased only in those teenage suicide subjects who had a history of mental illness. These results indicate an impairment in the expression of $G_{s} \alpha_{-s}$, $\mathrm{G}_{\mathrm{i} 2 \alpha}$, and $\mathrm{G}_{\mathrm{O}} \alpha$ subunits only in suicide subjects who had a history of mental disorders. Given the functional significance of $G$ proteins in mediating various physiological functions, such alterations in the levels of $\mathrm{G}_{\mathrm{s}} \alpha_{-\mathrm{S}}, \mathrm{G}_{\mathrm{i} 2 \alpha}$, and $\mathrm{G}_{\mathrm{O}} \alpha$ subunits may be of relevance in the pathophysiology of mental disorders.

\section{ACKNOWLEDGMENTS}

This work was supported by grants from the National Institute of Mental Health RO1MH 48153-04 to Dr. G.N. Pandey and National Institute of Mental Health Career Development Award KO1MH01836 and Young Investigator Award from American Foundation For Suicide Prevention to Dr. Y. Dwivedi. We acknowledge with thanks the cooperation of Dr. John Smialek, Chief Medical Examiner, State of Maryland, and Dr. Dennis Chute, Assistant Medical Examiner, in the collection of brain samples; and thanks to Ms. Terri U'Prichard for performing the psychological autopsies, and to Dr. Boris Lapidus for the dissections. We also thank Ms. Miljana Petkovich and Ms. Barbara Brown for organizing the brain tissues.

\section{REFERENCES}

Apter A, Gothelf D, Orbach I, Har-Even D, Weizman R, Tyano S (1995): Correlation of suicidal and violent behavior in different diagnostic categories in hospitalized adolescent patients. J Am Acad Adolesc Psychiat 34:911-918

Avissar S, Barki-Harrington L, Herishanu Y, Schreiber G (1997): Reduced $\mathrm{G}_{\mathrm{s}}$ function and $\mathrm{G} \alpha_{\mathrm{s}}$ levels in leukocytes of patients with Parkinson's disease. Mov Disord 12:167-174

Birnbaumer L, Abramowitz J, Yatani A, Okabe K, Mattera R, Graf R, Sanford J, Codina J, Brown AM (1990): Roles of $\mathrm{G}$ proteins in coupling of receptors to ionic channels and other effector systems. Crit Rev Biochem Mol Biol 25:225-244

Bray P, Carter A, Guo V, Puckett C, Kamholz J, Spiegel A, Nirenberg M (1987): Human cDNA clones for an alpha subunit of Gi signal-transduction protein. Proc Natl Acad Sci USA 987:5115-5119

Bray P, Carter A, Simons C, Guo V, Puckett C, Kamholz J, Spiegel A, Nirenberg M (1986): Human cDNA clones for four species of $\mathrm{G}$ alpha s signal transduction protein. Proc Natl Acad Sci USA 83:8893-8897

Brent D, Kolko D, Wartella M, Boylan M, Moritz G, Baugher M, Zelenak J (1993): Adolescent psychiatric inpatients' risk of suicide attempt at 6-month follow-up. J Am Acad Child Adolesc Psychiatry 32:95-105

Clapham DE, Neer EJ (1997): G protein beta gamma subunits. Annu Rev Pharmacol Toxicol 37:167-203

Cowburn RF, Marcusson JO, Eriksson A, Wiehager B, O'Neill C (1994): Adenylyl cyclase activity and G-protein subunit levels in postmortem frontal cortex of suicide subjects. Brain Res 633:297-304

Daaka Y, Luttrell LM, Lefkowitz RJ (1997): Switching of the 
coupling of the beta2-adrenergic receptor to different $G$ proteins by protein kinase A. Nature 390:88-91

Didsbury JR, Ho YS, Snyderman R (1987): Human Gi protein alpha-subunit: deduction of amino acid structure from a cloned cDNA. FEBS Lett 211:160-164

Dwivedi Y, Pandey GN (1997): Effects of subchronic administration of antidepressants and anxiolytics on levels of the $\alpha$ subunits of $G$ proteins in the rat brain. J Neural Transm Gen Sect 104:747-760

Dwivedi Y, Rizavi HS, Roberts RC, Conley RR, Tamminga CA, Pandey GN (2001): Reduced activation and expression of ERK1/2 MAP kinase in the post-mortem brain of depressed suicide subjects. J Neurochem 77:916-928

Dwivedi Y, Conley RR, Roberts RC, Tamminga CA, Pandey GN (2002): $\left[{ }^{3} \mathrm{H}\right]$ cAMP binding sites and protein kinase A activity in the prefrontal cortex of suicide victims. Am J Psychiatry 159:66-73

Freissmuth M, Waldhoer M, Bofill-Cardoba E, Nanoff C (1999): $G$ protein antagonists. Trends Pharmacol Sci 20:237-245

Friedman E, Wang H-Y (1996): Receptor-mediated activation of $G$ proteins is increased in postmortem brains of bipolar affective disorder subjects. J Neurochem 67:1145-1152

Garcia-Sevilla JA, Escriba PV, Ozaita A, La Harpe R, Walzer C, Eytan A, Guimon J (1999): Upregulation of immunolabeled [alpha] ${ }_{2 \mathrm{~A}}$-adrenoceptors $\mathrm{G}_{\mathrm{I}}$ coupling proteins, and regulatory receptor kinases in the prefrontal cortex of depressed suicides. J Neurochem 72: 282-291

Garcia-Sevilla JA, Walzer C, Busquets X, Escribá PV, Balant L, Guimón J (1997): Density of guanine nucleotide-binding proteins in platelets of patients with major depression: increased abundance of the $\mathrm{G} \alpha_{\mathrm{i} 2}$ subunit and down-regulation by antidepressant drug treatment. Biol Psychiatry 42:704-712

George MS, Ketter TA, Post RM (1994): Prefrontal cortex dysfunction in clinical depression. Depression 2:59-72

Gilman AG (1987): G proteins: transducers of receptor-generated signals. Ann Rev Biochem 56:615-649

Gross-Isseroff R, Biegon A, Voet H, Weizman A (1998): The suicide brain: a review of postmortem receptor/transporter binding studies. Neurosci Biobehav Rev 22:653-661

Gurguis GN, Antai-Otong D, Vo SP, Blakeley JE, Orsulak PJ, Petty F, Rush AJ (1999a): Adrenergic receptor function in panic disorder. I. Platelet alpha 2 receptors: Gi protein coupling, effects of imipramine, and relationship to treatment outcome. Neuropsychopharmacology 20:162-176

Gurguis GN, Blakeley JE, Antai-Otong D, Vo SP, Orsulak PJ, Petty F, Rush AJ (1999b): Adrenergic receptor function in panic disorder. II. Neutrophil beta 2 receptors: $G_{s}$ protein coupling, effects of imipramine treatment and relationship to treatment outcome. J Psychiatr Res 33:309-322

Hamm HE (1998): The many faces of G protein signaling. J Biol Chem 273:669-672

Hildebrandt JD (1997): Role of subunit diversity in signaling by heterotrimeric G proteins. Biochem Pharmacol 54:325-339

Hoffman PL, Tabakoff B (1990): Ethanol and guanine nucle- otide binding proteins: a selective interaction. FASEB J 4:2612-2622

Jones DT, Masters SB, Bourne HR, Reed RR (1990): Biochemical characterization of three stimulating GTP-binding proteins. The large and small forms of Gs and olfactoryspecific G protein, Golf. J Biol Chem 265:2671-2676

Jope RS, Long L, Grimes CA, Pachecco MA, Dilley GE, Li X, Meltzer HY, Overholser JC, Stockmeier CA (1998): Selective increases in phosphoinositide signaling activity and $G$ protein levels in postmortem brain from subjects with schizophrenia or alcohol dependence. J Neurochem 70:763-771

Lawler OA, Miggin SM, Kinsella BT (2001): Protein Kinase A-mediated phosphorylation of serine 357 of the mouse prostacyclin receptor regulates its coupling to $\mathrm{G}_{\mathrm{S}-\text {, }}$ to $\mathrm{G}_{\mathrm{i}-\boldsymbol{1}}$ and $\mathrm{G}_{\mathrm{q}-\mathrm{C}}$ Coupled effector signaling. J Biol Chem 276: 33596-33607

Lefkowitz RJ (1998): G protein-coupled receptors. III. New roles for receptor kinases and beta-arrestins in receptor signaling and desensitization. J Biol Chem 273:1867718680

Lesch K-P, Manji HK (1992): Signal-transducing G proteins and antidepressant drugs: evidence for modulation of $\alpha$ subunit gene expression in rat brain. Biol Psychiatry 32:549-579

Li X, Greenwood AF, Powers R, Jope RS (1996): Effects of postmortem interval, age, and Alzheimer's disease on G-proteins in human brain. Neurobiol Aging 17:115122

Liggett SB (1997): Molecular Basis of G Protein-Coupled Receptor Signaling. In Crystal R, West JB, Weibel ER, Barnes PJ (eds), The Lung: Scientific Foundations. New York, Raven Press pp 19-36

Luo X, Zeng W, Xu X, Popov S, Davignon I, Wilkie TM, Mumby SM, Muallem S (1999): Alternate coupling of receptors to Gs and $\mathrm{Gi}$ in pancreatic and submandibular gland cells. J Biol Chem 274:17684-17690

Manji HK (1992): G proteins: implications for psychiatry. Am J Psychiatry 149:746-760

Manji HK, Chen G, Shimon H, Hsiao JK, Potter WZ, Belmaker RH (1995): Guanine nucleotide-binding proteins in bipolar affective disorder: effects of long-term lithium treatment. Arch Gen Psychiatry 52:135-144

Mann JJ, DeMeo MD, Keillip JG, McBrick PA (1989): Biological correlates of suicidal behavior in youth. In Pfeffer CR (ed), Suicide Among Youth: Perspectives on Risk and Prevention. Washington, DC, American Psychiatric Press, pp 185-202

Marinissen MJ, Gutkind JS (2001): G-protein-coupled receptors and signaling networks: emerging paradigms. Trends Pharmacol Sci 22:368-376

McKenzie FR, Adie EJ, Milligan G (1991): Prostanoid-mediated downregulation of Gs in NG108-15 cells. Biochem Soc Trans 19:81S

Milligan G, Wise A, MacEwan JD, Grassie MA, Kennedy FR, Lee TW, Adie EJ, Kim GD, McCallum JF, Burt A, Carr IC, Svoboda P, Shah BH, Mullaney I (1995): Mechanism of agonist-induced G-protein elimination. Biochem Soc Trans 23:166-170

Neer EJ (1995): Heterotrimeric G proteins: organizers of transmembrane signals. Cell 80:249-257 
Ozawa H, Gsell W, Frölich L, Zöchling R, Pantucek F, Beckmann $H$, Riederer P (1993): Imbalance of the $G_{s}$ and $G_{i / O}$ function in post-mortem human brain of depressed patients. J Neural Transm 94:63-69

Pacheco MA, Stockmeier C, Meltzer HY, Overholser JC, Dilley GE, Jope RS (1996): Alterations in phosphoinositide signaling and G-protein levels in depressed suicide brain. Brain Res 723:37-45

Pandey GN, Dwivedi Y, Pandey SC, Conley RR, Roberts RC, Tamminga CA (1997): Protein kinase $C$ in the postmortem brain of teenage suicide victims. Neurosci Lett 228:111-114

Pandey GN, Dwivedi Y, Pandey SC, Teas SS, Conley RR, Roberts RC, Tamminga CA (1999): Low phosphoinositide-specific phospholipase $C$ activity and expression of phospholipase $C \beta_{1}$ protein in the prefrontal cortex of teenage suicide subjects. Am J Psychiatry 156:1895-1901

Pandey GN, Dwivedi Y, Rizavi HS, Ren X, Pandey SC, Pesold C, Roberts RC, Conley RR (2002): Higher expression of serotonin $5-\mathrm{HT}_{2 \mathrm{~A}}$ receptors in the postmortem brains of teenage suicide victims. Am J Psychiatry 159:419-429

Rajkowska G (1997): Morphometric methods for studying the prefrontal cortex in suicide victims and psychiatric patients. Ann N Y Acad Sci 836:253-268

Ross EM (1989): Signal sorting and amplification through G protein-coupled receptors. Neuron 3:141-152

Robishaw JD, Smigel MD, Gilman AG (1986): Molecular basis for two forms of the $G$ protein that stimulates adenylate cyclase. J Biol Chem 261:9587-9590

Salzman S, Endicott J, Clayton P, Winokur G (1983): Diagnostic Evaluation After Death (DEAD). Rockville, MD, National Institute of Mental Health, Neuroscience Research Branch.

Sastre M, Guimon J, Garcia-Sevilla JA (2001): Relationships between beta- and alpha2-adrenoceptors and $\mathrm{G}$ coupling proteins in the human brain: effect of age and suicide. Brain Res 898:242-255
Simon MI, Strathmann MP, Gautam N (1991): Diversity of G proteins in signal transduction. Science 252:802-808

Spiegel AM, Simonds WF, Jones TL, Goldsmith PK, Unson CG (1990): Antibodies against synthetic peptides as probes of G protein structure and function. Soc Gen Physiol Ser 45:185-195

Spitzer RL, Williams JB, Gibbon M, First MB (1992): The structured clinical interview for DSM-III-R (SCID). I: History, rationale, and description. Arch Gen Psychiatry 49:624-629

Stein MB, Chen G, Potter WZ, Manji HK (1995): G-protein level quantification in platelets and leukocytes from patients with panic disorder. Neuropsychopharmacology 15:180-186

Tamir J, Fawzi AB, Tamir A, Evans T, Northup JK (1991): G protein $\beta \alpha$ forms: identity of $\beta$ and diversity of $\alpha$ subunits. Biochemistry 30:3919-3926

Vawter MP, Freed WJ, Kleinman JE (2000): National Institute on Drug Abuse Intramural Research Program, National Institutes of Health, Baltimore, MD. Biol Psych 48:486-504

Walseth TF, Zhang HJ, Olson LK, Schroeder WA, Robertson RP (1989): Increase in $\mathrm{G}_{\mathrm{s}}$ and cyclic AMP generation in HIT cells. Evidence that the 45-kDa $\alpha$-subunit of $\mathrm{G}_{\mathrm{s}}$ has greater functional activity than the $52-\mathrm{kDa} \alpha$-subunit. J Biol Chem 264:21106-21111

Young LT, Li PP, Kish SJ, Siu KP, Kamble A, Hornykiewicz O, Warsh JJ (1993): Cerebral cortex $\mathrm{G}_{\mathrm{s}} \alpha$ protein levels and forskolin-stimulated cyclic AMP formation are increased in bipolar affective disorder. J Neurochem 61:890-898

Young LT, Warsh JJ, Li PP, Siu KP, Becker L, Gilbert J, Hornykiewicz O, Kish SJ (1991): Maturational and aging effects on guanine nucleotide binding protein immunoreactivity in human brain. Brain Res Dev Brain Res 61:243-248

Zigman JM, Westermark GT, LaMendola J, Steiner DF (1994): Expression of cone transducin, Gz alpha, and other G-protein alpha-subunit messenger ribonucleic acids in pancreatic islets. Endocrinology 135:31-37 